\title{
Restoration of Eutrophic Lakes with Fluctuating Water Levels: A 20-Year Monitoring Study of Two Inter-Connected Lakes
}

\author{
Meryem Beklioğlu ${ }^{1,2, *}$, Tuba Bucak ${ }^{1}$, Jan Coppens ${ }^{1}$, Gizem Bezirci ${ }^{1}$, Ü. Nihan Tavşanoğlu ${ }^{1}$, \\ A. İdil Çakıroğlu ${ }^{1}$, Eti E. Levi ${ }^{1}$, Şeyda Erdoğan ${ }^{1,3}$, Nur Filiz ${ }^{1}$, Korhan Özkan 1,4 \\ and Arda Özen 1,5 \\ 1 Limnology Laboratory, Department of Biological Sciences, Middle East Technical University, \\ Çankaya, 06800 Ankara, Turkey; tubabucak@gmail.com (T.B.); coppensjc@gmail.com (J.C.); \\ gizbezirci@gmail.com (G.B.); unyazgan@gmail.com (Ü.N.T.); ayseidil@gmail.com (A.İ.Ç.); \\ eti@thelevis.com (E.E.L.); erdogan.seyda@gmail.com (Ş.E.); nrflzster@gmail.com (N.F.); \\ korhan.ozkan@gmail.com (K.Ö.); ardaozen@gmail.com (A.Ö.) \\ 2 Kemal Kurdaş Ecological Research and Training Stations, Lake Eymir, \\ Middle East Technical University, Oran Mahallesi, Çankaya, 06400 Ankara, Turkey \\ 3 Department of Biology, Faculty of Science and Arts, Bozok University, 66900 Yozgat, Turkey \\ 4 Institute of Marine Sciences, Middle East Technical University, Erdemli, 33340 Mersin, Turkey \\ 5 Department of Forest Engineering, Çankırı Karatekin University, 18200 Çankırı, Turkey \\ * Correspondence: meryem@metu.edu.tr; Tel.: +90-312-210-5155
}

Academic Editor: Erik Jeppesen

Received: 5 September 2016; Accepted: 9 February 2017; Published: 16 February 2017

\begin{abstract}
Eutrophication continues to be the most important problem preventing a favorable environmental state and detrimentally impacting the ecosystem services of lakes. The current study describes the results of analyses of 20 year monitoring data from two interconnected Anatolian lakes, Lakes Mogan and Eymir, receiving sewage effluents and undergoing restoration. The first step of restoration in both lakes was sewage effluent diversion. Additionally, in hypertrophic Lake Eymir, biomanipulation was conducted, involving removal of benthi-planktivorous fish and prohibition of pike fishing. The monitoring period included high $(\mathrm{H})$ and low $(\mathrm{L})$ water levels $(\mathrm{WL})$ enabling elucidation of the effects of hydrological changes on lake restoration. In shallower Lake Mogan, macrophyte abundance increased after the sewage effluent diversion in periods with low water levels even at turbid water. In comparatively deeper Lake Eymir, the first biomanipulation led to a clear water state with abundant macrophyte coverage. However, shortly after biomanipulation, the water clarity declined, coinciding with low water level (LWL) periods during which nutrient concentrations increased. A second biomanipulation was conducted, mostly during high water level (HWL) period, resulting in a major decrease in nutrient concentrations and clearer water, but without an expansion of macrophytes. We conclude that repetitive fish removal may induce recovery but its success may be confounded by high availability of nutrients and adverse hydrological conditions.
\end{abstract}

Keywords: benthivorous fish; biomanipulation; clear water; climate change; drought; flushing; sewage effluent diversion; Mediterranean

\section{Introduction}

Freshwater ecosystems provide a wide range of ecosystem services to society such as food, marketable goods, nutrient recycling, and recreation. Today, all of these services have been damaged to an unprecedented level due to an increase in land use and urbanization. The services are expected to deteriorate even further in the future due to the growing demands of the consumer society with an 
increasing population [1]. This calls for a much larger agricultural production with stronger needs for fertilization and irrigation in dry regions, which will likely result in further degradation of the quality and quantity of water bodies [2-4]. The demand for more water for irrigated crop farming in semi-arid to arid regions constitutes a major threat to the functioning of lake ecosystems as it alters the hydrological properties of lakes such as the hydraulic residence time and water level fluctuations (WLF), both of which are very significant for the functioning of freshwater ecosystems [3-8].

Climate warming may lead to changes in a variety of lake processes (e.g., decrease in oxygen concentrations, phosphate release from the sediment, and changes in nitrification/denitrification $[9,10])$ and may affect the trophic structure through changes in the size of various organisms as well as in community structure and composition [11,12]. As there is a strong linkage between climate and the hydrological cycle, warming can also create frequent periods of drought especially in the Mediterranean area $[13,14]$, with strong negative implications such as water level reduction in lakes [7,15]. According to the existing climate models for the Mediterranean region, more dramatic changes in the freshwater availability are expected to occur due to a predicted decrease in precipitation [16,17]. Moreover, rising temperatures [16] and frequent drought periods will likely lead to a greater demand for water resources for irrigation and drinking water, with larger water diversions, consequent water level declines, and severe basin-wide water shortages [18]. Despite the fact that decreased precipitation may lead to a lower external nutrient input due to the reduced hydraulic loading, eutrophication may still be intensified owing to the declining lake volume caused by higher evaporation and lower precipitation [3-6,19]. Eutrophication may also be further exacerbated by internal nutrient loading under warmer, likely anoxic, conditions. In addition, salinization may also create serious complications during severe droughts $[7,20]$.

Major efforts have been made to control eutrophication in many parts of the world by reducing the external nutrient loading. However, the eutrophic state along with algal blooms, especially cyanobacteria, has persisted due to chemical or biological resilience created by internal phosphorus $(\mathrm{P})$ loading from the sediment [21], weaker top down control, as well as disturbance of the sediment by foraging plankti-benthivorous fish [22-24]. To overcome chemical and biological within-lake resilience and boost recovery, a number of biological and physico-chemical restoration methods have been developed [7,25-28]. In north temperate lakes, biomanipulation of the fish community has led to the recovery of lakes, but maintenance of the clear-water state requires a sufficiently extensive fish removal (about $1-2$ years) and sustaining continuous low TP levels $(<0.05 \mathrm{mg} \mathrm{P} / \mathrm{L}$ and $<0.02 \mathrm{mg}$ $\mathrm{P} / \mathrm{L}$ for shallow and deep temperate lakes, respectively) [26,29-32]. Otherwise, the impact of fish manipulation will be brief $[3,26,33]$ as fish will quickly recover due to the reduction of the competition in the remaining population. However, it is debatable whether the fish manipulation approach used in northern temperate lakes can be used with similar success in warm and Mediterranean lakes with their distinctively different hydrology [33,34]. In Mediterranean lakes, omnivorous small fish with fast growth rates and longer duration of spawning are common along with weaker top-down control from piscivorous fish [35-37], rendering biomanipulation more difficult to provoke and to maintain a trophic cascade effect.

Hydrological management may also help to improve water clarity by providing favorable conditions for macrophytes. For example, dilution or flushing can be an effective technique to reduce the concentrations of nutrients and salt by adding nutrient- and salt-poor water [25]. Furthermore, it may reduce algal blooms by increasing the loss rate of the cells. Flushing has been very effective in temperate lakes [38], and it has a great potential as a restoration tool in Mediterranean lakes [19]. In addition to this, water level reduction may also allow extensive growth of macrophytes by increasing the littoral habitat $[7,25,39]$. Accordingly, mesocosm studies in Turkish shallow lakes have shown that macrophytes may persist under eutrophic to hypertrophic conditions due to significant evaporation-triggered water level reduction during summer, the positive effects of which may override the negative effects of the eutrophication-induced turbid conditions [40,41]. 
Macrophyte abundance and distribution are associated with the provision of several ecosystem functions or services that meet various societal needs [42]. Due to their fundamental structuring role, their re-establishment and protection characteristics are thus of key importance for the long-term recovery of shallow temperate lakes and, traditionally, restoration efforts in shallow lakes have focused on creating favorable conditions for the re-establishment of macrophytes [27,43]. However, macrophytes may potentially play a weaker role for water clarity in warm lakes by being a less effective refugium for zooplankton [44-46].

Furthering our understanding of the responses of lake ecosystems to the changing climate is of the utmost importance in being able to contribute to their conservation with adequate mitigation $[47,48]$ and adaptation measures [49]. In this study, we explored 20 years of monitoring data, covering low water level (LWL) and high water level (HWL) periods, from two Central Anatolian lakes-Lake Mogan and Lake Eymir-located in cold dry steppe climate. Prior to the start of the monitoring, both lakes received sewage effluent from a nearby town, causing the lakes to become eutrophic. For the purpose of restoration the sewage effluent was diverged from both lakes, and Lake Eymir was biomanipulated for two distinct time periods. These two lakes provided an ideal opportunity to study the impacts of hydrological changes on lake ecosystem structure as well as on restoration efforts. We hypothesized that the success of biomanipulation as well as the stability of the recovery depend strongly on nutrient and hydrological conditions. Accordingly, we expected that: (i) low water levels and prolonged hydraulic residence times would enhance eutrophication and counteract the biomanipulation-induced recovery in hypereutrophic Lake Eymir; (ii) high water levels and flushing associated with the second fish removal would enhance recovery and thus the water clarity, enabling recolonization of submerged macrophytes; (iii) the maintenance of macrophytes in shallow Lake Mogan would depend largely on the hydrological conditions, low water levels might induce the expansion of macrophytes even in turbid water.

\section{Materials and Methods}

\subsection{Study Sites}

The study comprised one shallow and one relatively deep interconnected alkaline lakes (average alkalinity $>6.5 \mathrm{meq} \cdot \mathrm{L}^{-1}$ for both lakes), Lake Mogan $\left(39^{\circ} 47^{\prime} \mathrm{N}, 32^{\circ} 47^{\prime} \mathrm{E}\right)$ and Lake Eymir $\left(39^{\circ} 57^{\prime} \mathrm{N}\right.$, $32^{\circ} 53^{\prime} \mathrm{E}$ ), situated $20 \mathrm{~km}$ south of Ankara at an elevation of $970 \mathrm{~m}$ on the Anatolian plateau in Central Turkey (Figure 1). Upstream Lake Mogan (area: $5.6-8 \mathrm{~km}^{2}$, mean depth: 2.4 , max depth: 2.8-5.3 m) and downstream Lake Eymir (area: 1-1.3 $\mathrm{km}^{2}$, mean depth: $3.2 \mathrm{~m}$, max depth: 3.4-6.5 m) are physically located within the Mediterranean climatic region. However, the high elevations of the Anatolian plateau (>1000 m) cause deviations from the typical Mediterranean climate. The lakes are predominately exposed to a Central Anatolian arid-cold steppe climate [50] with hot, dry, and long summers starting in June and lasting until November (as in the Mediterranean climate), but with cold-rainy and snowy winters. The average annual temperature is $12^{\circ} \mathrm{C}$, which has been slowly increasing (from $11.2{ }^{\circ} \mathrm{C}$ in 1980 to $13.2{ }^{\circ} \mathrm{C}$ in 2013), with a minimum of $-8^{\circ} \mathrm{C}$ and a maximum of $36^{\circ} \mathrm{C}$. In the catchment of the lakes, total precipitation averaged approximately $408 \mathrm{~mm}$, alternating between dry and wet periods ( $<350 \mathrm{~mm}$ and $>500 \mathrm{~mm}$, respectively) [19,51] (Figure 2), and in the summers, evaporation has always been significantly higher than precipitation. This creates a distinctive hydrology associated with periodic droughts, leading to annual and inter-annual large water level fluctuations [52] as an inherited characteristic of Mediterranean lakes. Overall, our study lakes can be still classified as Mediterranean lakes due to their distinctive hydrological features associated with the hot summers, despite the cold winter conditions. 


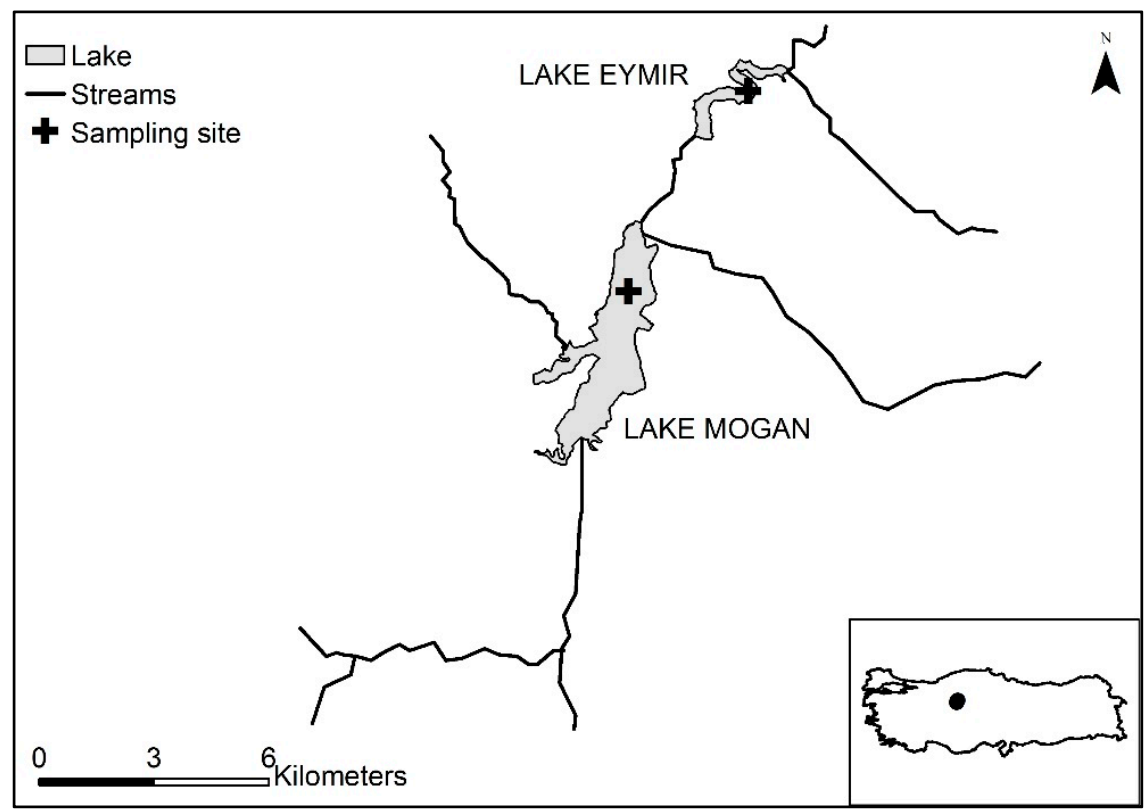

Figure 1. Location of the study lakes and sampling sites. The map is modified from Coppens et al. [19].

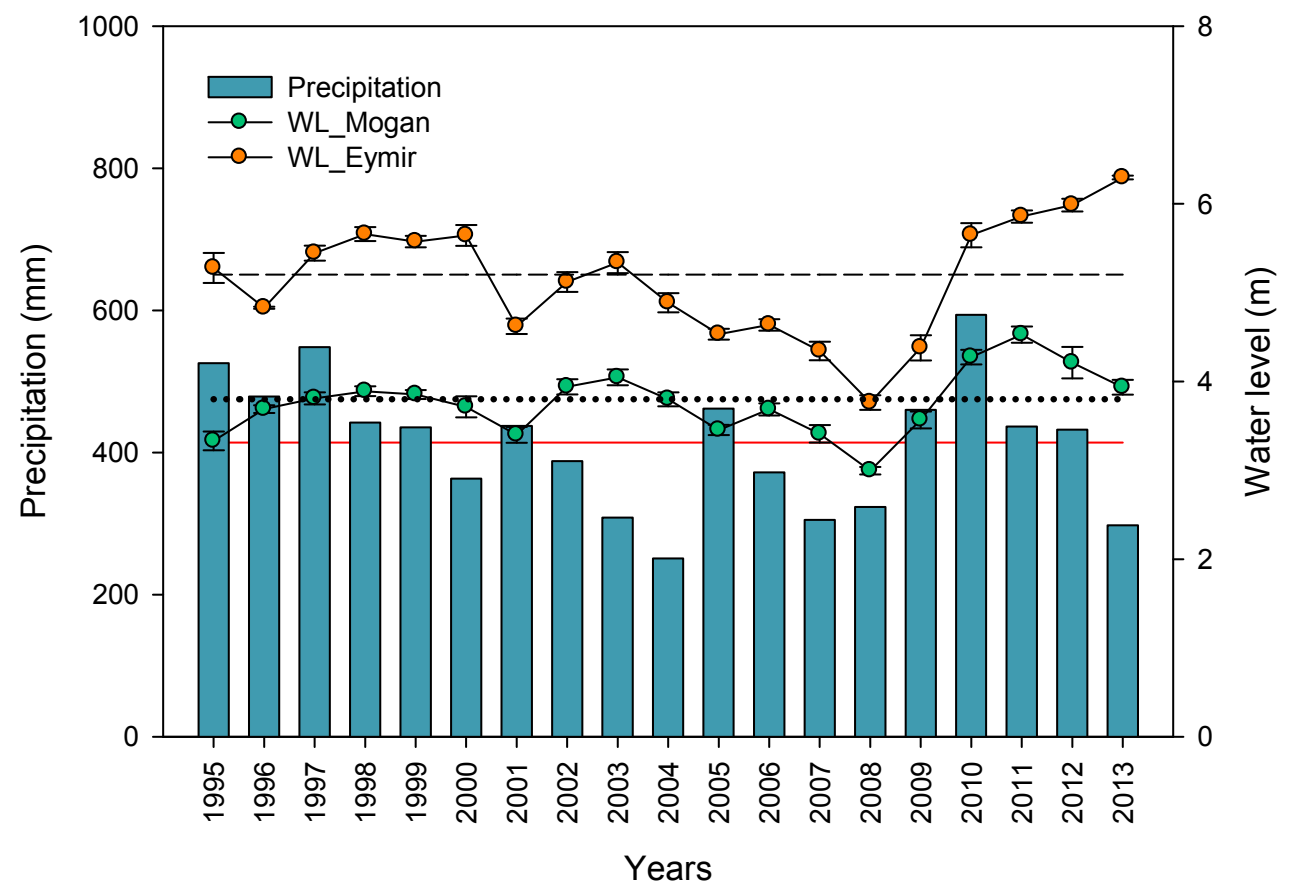

Figure 2. Changes in total annual precipitation and average water levels of Lakes Mogan and Eymir between 1995 and 2013. Red solid line indicates average annual precipitation, black dotted and black dashed lines indicate long term average water levels for Lake Mogan and Lake Eymir, respectively (data source for precipitation: Turkish State Meteorological Service [51]).

The catchment area of the lakes covers $1010 \mathrm{~km}^{2}$, and $68 \%$ of the catchment consists of agricultural land dominated by non-irrigated crops, mostly wheat. Although both lakes and their surroundings mainly fulfill urban housing and recreational needs, the wildlife and biodiversity value of the lakes are high. For instance, the area hosts more than 26 mammal species and 231 bird species, of which 76 are breeding [53,54], as well as the endemic plant species Centuarea tchihatcheffii. Both lakes are designated 
as "Specially Protected Areas", and Lake Mogan has been declared an "Important Bird Area" by the Ministry of Environment and Urbanization.

Upstream Lake Mogan is fed by both groundwater and surface flows, with four major streams that run throughout the year as the main inflows and several ephemeral streams [19]. The outflow of the lake, which has been regulated since 1974 [55], flows through a wetland and feeds downstream Lake Eymir through both surface and ground waters (Figure 1). In addition to the upstream inflow from Lake Mogan, Lake Eymir receives ephemeral inflow, which is active during the spring snow-melt [19]. The outflows of both of the lakes are regulated to control incidence of flooding to the low-lying areas of the capital city of Ankara. Using annual precipitation amounts generally agreed with changes in water levels (high/low) but it also failed. Although the annual precipitation amounts were higher in 2001 and 2005 than the long-term average, the lakes had LWL due to mismanagement of the water level through excessive release of water from the lakes to prevent the risk of flooding (Figure 2). Whereas in 2002,2003 , and 2004 when the annual precipitations were much lower than the long-term average, the lakes' levels remained high or did not change (Figure 2). This was probably due to not letting water out during a drought period. Hence, we made a distinction between low water level (LWL) years and high water level (HWL) years based on the annual average water level rather than on total annual precipitation (Figure 2). This implies that the hydrological regimes are artificial even though both lakes are naturally formed [19]. Therefore, the water level classification is performed in comparison to the long-term average water level. For Lake Mogan, the LWL years were 1995-1996, 2000-2001, and 2005-2009, with water levels below $3.8 \mathrm{~m}$, and the HWL years were 1997-1999, 2002-2004, and 2010-2013, with water levels above $3.8 \mathrm{~m}$ (Figure 2). In the LWL years, the hydrological residence time (HRT) varied between 11 years and theoretically infinite, while for the HWL years, the HRT varied between 1.14 and 17 years. For Lake Eymir, the LWL years were 1996, 2001-2002, and 2004-2009 with an average annual water level below $5.2 \mathrm{~m}$ (the long-term average water level) (Figure 2), and the HWL years were 1995, 1997-2000, 2003, and 2010-2013, with an average annual water level above $5.1 \mathrm{~m}$ [19]. In the LWL years, the HRT varied between 6.8 years and theoretically infinite, while for the HWL years, it was $0.2-6.25$ years.

Lake Mogan was in a clear-water state with high macrophyte abundance in 1997, with dominance of Chara beds and pondweed (Stuckenia pectinata) with low chlorophyll a (Chl-a) $\left(8.8 \pm 2 \mu \mathrm{g} \cdot \mathrm{L}^{-1}\right)$ and moderate total phosphorus (TP) $\left(63 \pm 5 \mu \mathrm{g} \cdot \mathrm{L}^{-1}\right)$ levels [55]. Lake Eymir served as a drinking water supply for the Middle East Technical University before the 1990s, which hosts the lake and its catchment. However, between 1970 and 1995, the lake received input of raw sewage effluents from the nearby town of Gölbaş1, located between the two lakes. This resulted in deterioration of the water quality and the lake could no longer serve as a drinking water source [56,57]. In 1995, a sewage effluent diversion program was implemented to restore Lake Eymir, involving the control of the sewage disposal of a small number of restaurants and urban structures found in close proximity to Lake Mogan that resulted in a reduction of the external loading by $88 \%$ [56].

\subsection{Fish Samplings and Biomanipulation}

In Lake Mogan, fish sampling was initiated in 2007 and conducted annually until 2013, during the peak of the growing season. In Lake Eymir, fish sampling was carried out once in May 1998, prior to the biomanipulation, and once in 1999 during the biomanipulation. Furthermore, additional fish samplings were conducted annually from 2000 to 2013 (except 2006). Until 2005, fish samplings were conducted using multiple mesh-sized gill nets (length: $100 \mathrm{~m}$, height: $3.5 \mathrm{~m}$ ) and in 2005 three additional mesh sizes (between 50 and $90 \mathrm{~mm}$ ) were added to the nets. From 2007 to 2013, fish surveys were conducted with $30 \mathrm{~m}$ long, $1.5 \mathrm{~m}$ high Nordic benthic multiple-mesh gillnets, containing 12 sections with different mesh sizes varying between 5.0 and $55.0 \mathrm{~mm}$. For each survey, an equal number of nets were set parallel to the shore in both pelagic and littoral zones of the lakes and left overnight for $12 \mathrm{~h}$ [20]. In total, 8 sets of gillnets were used in Lake Eymir and 10 sets in Lake Mogan. Subsequent to collecting the nets, fish were identified to the species level according to Balık and Geldiay [58], 
Kuru [59], Alas and Solak [60], and weight was determined to calculate biomass per unit effort (BPUE) as catch per net per night.

In Lake Eymir, two periods of biomanipulations were conducted during the growing seasons (April to October) using multiple-mesh gill nets $(50,65,80 \mathrm{~mm}$ ) with a length varying between 750 and $1800 \mathrm{~m}$ to reduce the biomass of common carp (Cyprinus carpio) and tench (Tinca tinca). The first biomanipulation period was during 1998-1999 and the second period from late 2005 to late 2013. The nets were placed perpendicular to the shore in the littoral zone, left overnight, and retrieved the following morning. Fish removal was carried out during the weekdays by contracted local fishermen as the lake was used extensively for recreational activities by large numbers of visitors during the weekends. As part of the lake restoration effort, pike (Esox lucius) angling was banned to increase the piscivorous fish population [56].

\subsection{Water Sampling}

Samplings were conducted biweekly at the same sampling point during the growing season (March-November) and monthly during the winter. No samples were taken during the ice-covered periods in 1997-2013. Chemical data on the lakes from 1993 to 1995 are taken from Altınbilek et al. [57]. In situ measurements of physical variables, salinity and temperature were conducted using a YSI 556 MPS multi-probe field meter (YSI Incorporated, Yellow Springs, OH, USA), and Secchi depth was recorded using a white disc with a diameter of $20 \mathrm{~cm}$. For the chemical and biological analyses, $40 \mathrm{~L}$ of water was retrieved, from the deepest points of the lakes from the whole water column using a water sampler (volume: 3.5 L, KC-Denmark, Silkeborg, Denmark). Water samples for chemical analysis were kept frozen until analysis. For cyanobacteria enumeration, a 100-mL unfiltered water sample was preserved in $2 \%$ Lugol's solution. Twenty litres of water (from the same $40 \mathrm{~L}$ mixed water sample) was filtered through a $20 \mu \mathrm{m}$ mesh size filter for zooplankton enumeration and preserved in Lugol's solution $(4 \%)$.

\subsection{Macrophyte Sampling}

To estimate the aquatic plant coverage, submerged and floating-leaved plants were surveyed once a year from 1997 in Lake Eymir and from 2001 until 2013 in Lake Mogan. The estimation was done along parallel transects at $320 \mathrm{~m}$ and $200 \mathrm{~m}$ intervals in Lakes Mogan and Eymir, respectively, as described by Levi et al. [61]. The sampling points along each transect were located at $245 \mathrm{~m}$ and $120 \mathrm{~m}$ intervals and the average number of sampling points throughout the survey period were 90 and 70 , in Lakes Mogan and Eymir, respectively. GPS coordinates, water depth, Secchi depth, species identity, and percent coverage of each species were recorded at each sampling point. The cover of each plant species was estimated in a quadrat at each point, and the average percent plant cover of each lake was calculated by dividing the total plant cover measured in the field by the number of sampling points. The plant species were identified using Davis [62], Seçmen, and Leblebici [63].

\subsection{Laboratory Analyses}

For determination of total phosphorus (TP) and soluble reactive phosphate (SRP) concentrations, the acid hydrolysis method was used [64]. For estimation of dissolved inorganic nitrogen (DIN), including the summation of nitrite-nitrate $\left(\mathrm{NO}_{2}+\mathrm{NO}_{3}-\mathrm{N}\right)$ and ammonium $\left(\mathrm{NH}_{4}\right)$, the Skalar Autoanalyzer method was applied (San++ Automated Wet Chemistry Analyzer, Skalar Analytical, B.V., Breda, The Netherlands). Chl- $a$ was determined by using the ethanol extraction method [65], and the absorbance was measured at 663 and $750 \mathrm{~nm}$.

Phytoplankton biomass was estimated from Chl-a [66] using a conversion factor of $1 / 66$ ( $\mu \mathrm{g}$ Chl- $a, \mu \mathrm{g}$ dry weight (DW)). Cyanobacteria biovolume was calculated according to appropriate geometric shapes [67,68]; at least 10 individuals from each species were measured and their mean volume was used for the biovolume calculations. Identification of species was performed using taxonomic reference books $[69,70]$. 
All zooplankton taxa were identified to genus or, whenever possible, to species level and counted until 50-100 individuals of the most abundant taxa had been identified. Counting was performed at $40 \times$ magnification (cladocerans and copepods) using a stereomicroscope (LEICA MZ 16) and $630 \times$ (rotifers) with an inverted microscope (LEICA DMI 4000). For taxonomical identification, the keys developed by Scourfield and Harding [71], Ruttner-Kolisko [72], Pontin [73], Einsle [74], Segers [75], Smirnov [76], Flößner [77], and Smith [78] were used. For the calculation of dry weight of zooplankton from length, Dumont et al. [79], Bottrell et al. [80], McCauley [81], Malley et al. [82], and Michaloudi [83] were used.

\subsection{Statistical Analysis}

The relationship between water level and salinity was analyzed with linear regression. A generalized linear model (GLM) was applied to determine the drivers contributing to the change in Chl- $a$ concentrations. The annual averages of the data were log-transformed prior to the analyses. Water temperature, zooplankton, and TP were chosen as predictor variables for the Chl- $a$ concentration. $\mathrm{R}$ version 3.2.5 [84] was used to perform the GLM analysis and the linear regression.

To investigate the depth-area relationships of the lakes, hypsographic curves were generated by creating binned histograms using the Reclassify tool in ArcGIS 10.1 [85]. Furthermore, to investigate the impact of water level and clarity changes on aquatic plants, these generated hypsographic curves were examined together with maximum water depth, Secchi depth, and submerged plant coverage from 1995 to 2013 (note that the plant surveys started in 1997 in Lake Eymir and in 2001 in Lake Mogan).

A regression tree was constructed to reveal the relative importance of water level and Secchi depth as potential predictors of a response variable for macrophyte coverage in each lake [86]. In our study, we used conditional inference trees (CIT) [87] where data are recursively partitioned into smaller groups - branches-and binary splits are selected based on maximization of the homogeneity of the two resulting groups. The macrophyte data used in the regression trees covered the period from 2001 to 2013 for both lakes. The party (A Laboratory for Recursive Partitioning) R package [88] was used for analyses.

\section{Results}

\subsection{Hydrology and Salinity}

The water level in the two study lakes fluctuated markedly both inter- and intra-annually (Figure 3). Annual water level fluctuations (WLF) averaged $\pm 0.60 \mathrm{~m}$ in Lake Mogan and $\pm 0.65 \mathrm{~m}$ in Lake Eymir. The salinity levels in both lakes more than doubled from 1.0\% to approximately $2.9 \%$ during the low water level conditions (Figure 3), the increase being largest in Lake Mogan, having a surface area six times larger than that of Lake Eymir. Regression analysis revealed that the water level change was a significant factor in explaining the variation in salinity of the two lakes ( $p: 0.006$ and 0.025 for Lakes Mogan and Eymir, respectively).
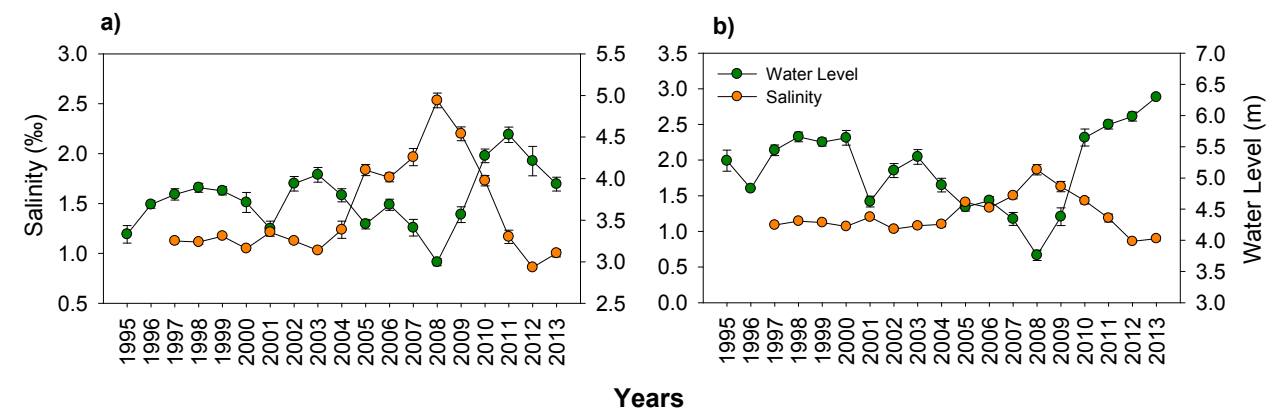

Figure 3. Changes in yearly mean (with \pm SE) salinity and water level in (a) Lake Mogan and (b) Lake Eymir. Note the scale differences on the $y$-axes. 


\subsection{Fish Community and Biomanipulation}

In both lakes, the fish community was composed of carp, bleak (Alburnus alburnus), tench, and pike, as well as invasive species topmouth gudgeon (Pseudorasbora parva) (Figure 4a,b). Highest BPUE (dominated by bleak, carp, and tench) was recorded in 2008-2009 during the LWL period (Figure 4a,b). In Lake Eymir, after the first biomanipulation (1998-1999), BPUE was low; however, it later recovered (Figure $4 \mathrm{~b}$ ) and the increase in bleak biomass following the first fish removal was considerable (Figure 4b). The second biomanipulation (2005-2013) produced a temporary decline in the BPUE of carp, tench, and bleak (Figure $4 b$ ). However, there was a considerable increase in BPUE in 2008-2009 when the water level was the lowest. This also coincided with a peak in fish removal, with a total biomass of 18 tons of carp and 7 tons of tench per year removed.
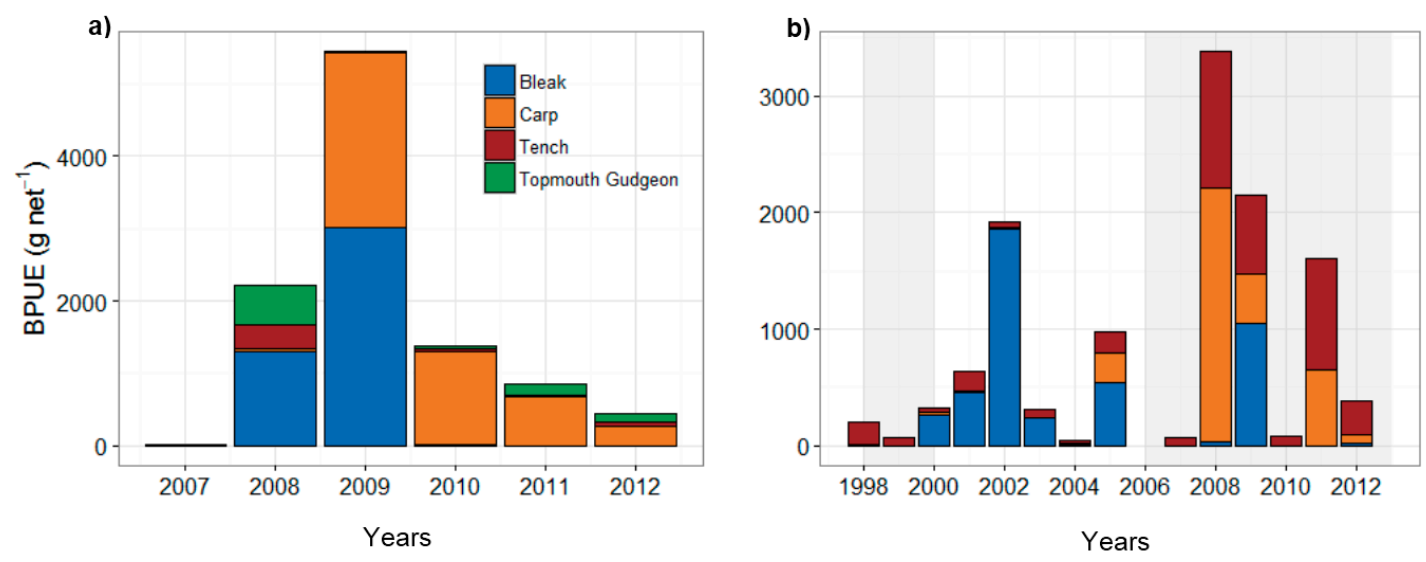

Figure 4. Biomass of the dominant fish species $\left(g \cdot\right.$ net $^{-1}$ ) in (a) Lake Mogan and (b) Lake Eymir (shaded periods indicating the first and second biomanipulation). Note the scale differences on the $y$ and $x$-axes.

\subsection{Nutrients and Water Transparency}

At the start of the study, the water transparency of the lakes differed substantially as Secchi depth was high in Lake Mogan and low in Lake Eymir (Figure 5a,b). In Lake Mogan, water transparency gradually decreased with an increase in SS concentrations, whereas in Lake Eymir, water transparency more than doubled during the first biomanipulation. Unfortunately, no SS data just prior to the first biomanipulation is available for Lake Eymir, except from 1995 to 1996 where SS concentration was very high. After the first biomanipulation Secchi depth gradually declined, but subsequently increased during the second biomanipulation, though it largely fluctuated afterwards (especially after 2009, coinciding with HWLs).

Data for the lakes before sewage effluent diversion are limited. However, a general reduction of concentrations of both $\mathrm{P}$ (TP and SRP) and DIN $\left(\mathrm{NH}_{4}-\mathrm{N}+\mathrm{NO}_{3}-\mathrm{N}\right)$ was observed in both lakes following the diversion (Figure 6a-d). Following the sewage effluent removal in Lake Mogan, P concentrations varied substantially over the study period without exhibiting any clear pattern, peaking in 2000, 2004, and 2008, and then dropped. The highest peak, which occurred in 2008, coincided with the lowest water level (Figure 6a). DIN concentrations also varied substantially, with minor peaks in 2003 and 2012 (Figure 6c). The contributions of ammonium $\left(\mathrm{NH}_{4}-\mathrm{N}\right)$ and nitrate $\left(\mathrm{NO}_{3}-\mathrm{N}\right)$ to DIN were similar, yet an increase in $\mathrm{NO}_{3}-\mathrm{N}$ concentration appeared in recent years. DIN:SRP ratio varied around 15 following the sewage effluent diversion excluding the three lowest ratios occurring in 2008, 2010, and 2013 (Figure 6e). 


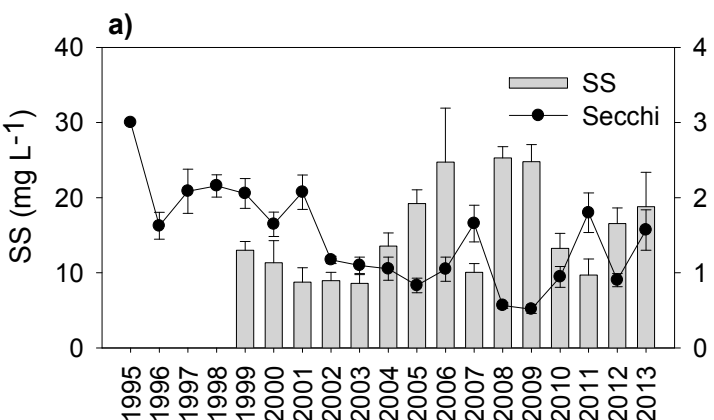

b)

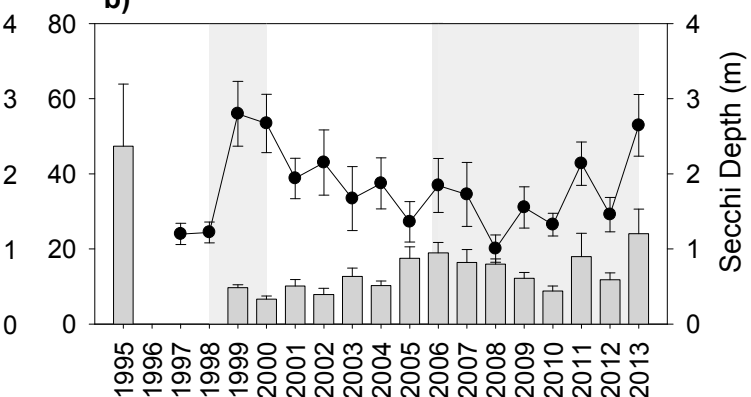

Years

Figure 5. Changes in yearly mean (with \pm SE) water transparency (Secchi depth) and concentrations of suspended solids (SS) from 1995 to 2013 for (a) Lake Mogan and (b) Lake Eymir (shaded periods indicate the first and second biomanipulations). Note the scale differences on the $y$-axes.
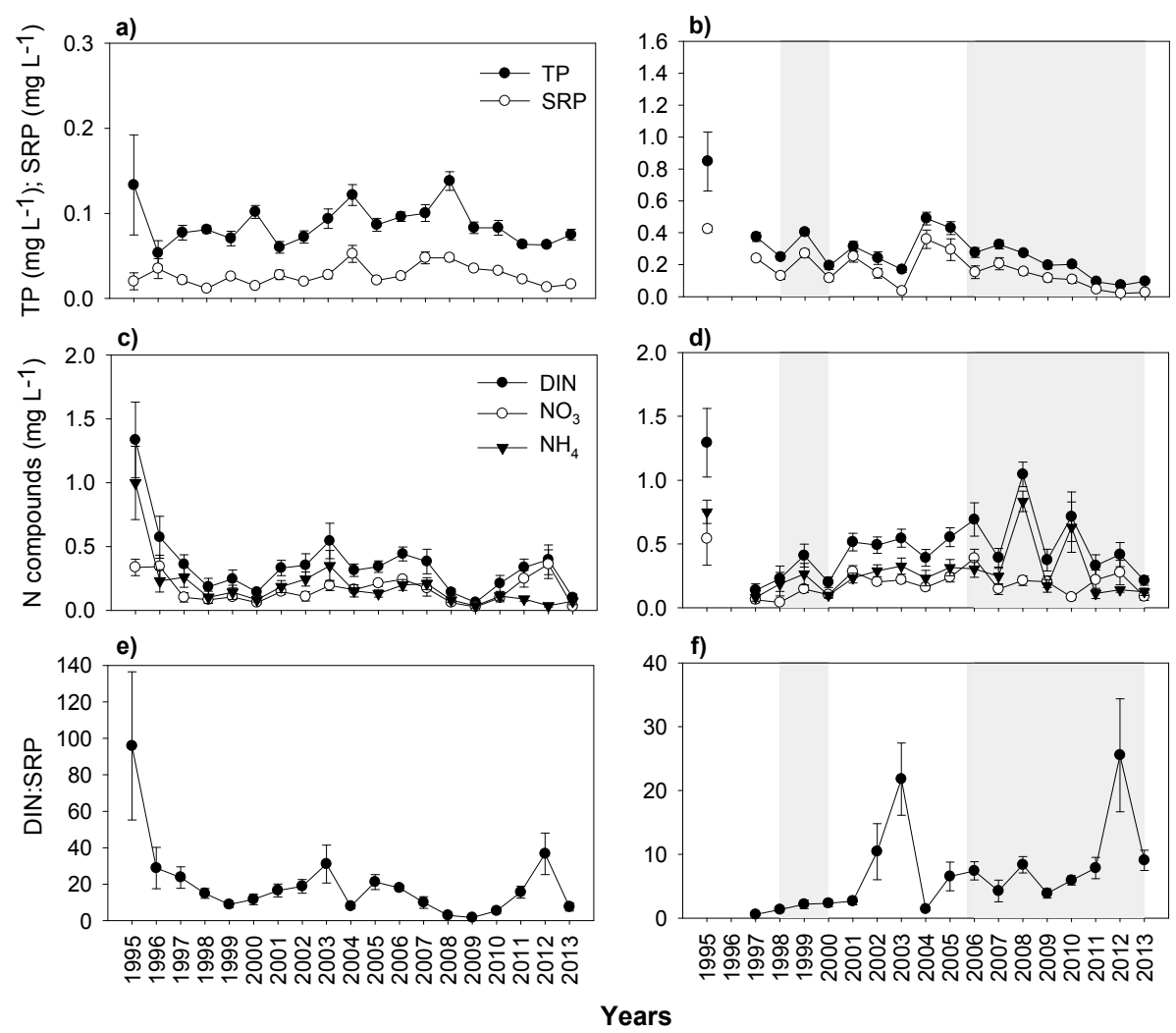

Figure 6. Changes in yearly mean (with \pm SE) nutrient concentrations from 1995 to 2013 in Lake Mogan (left panels) and Lake Eymir (right panels); (a,b) total phosphorus and soluble reactive phosphate (TP-SRP); (c,d) Nitrogen compounds; (e,f) dissolved inorganic nitrogen: soluble reactive phosphate (DIN:SRP) (shaded periods indicate the first and second biomanipulation periods). Note the scale differences on the $y$-axes.

In Lake Eymir, the concentrations of TP and SRP demonstrated a general decrease over a 20-year period reflecting the effect of sewage effluent diversion. The decline was especially prominent following the biomanipulations. However, there was a peak in TP concentration in 2004 just before the second biomanipulation, coinciding with the LWL period (Figure 6b). However, TP concentration showed a trend of decrease probably owing to the fish removal taken place during the second biomanipulation as well as high flushing rate, occurring during the subsequent HWL (2010-2013). 
The DIN concentrations increased between the periods of two biomanipulations, and then varied pronouncedly with a major contribution from ammonium especially during the lowest water level year, 2008 (Figure 6d). The DIN:SRP ratio remained very low throughout the study period except in 2002-2003 and 2012 (Figure 6f).

\subsection{Macrophytes}

Najas marina and Stuckenia pectinata (also known as Potamogeton pectinatus) dominated the submerged plant community in shallow Lake Mogan. Conditional inference tree (CIT) analysis carried out to determine the role of water depth and clarity on macrophyte coverage revealed that water depth defined the first splits, with the dataset including water depths $\geq 319 \mathrm{~cm}$ exhibiting an average plant coverage of $13 \%$ (Figure 7a). In addition, water depth $\leq 319 \mathrm{~cm}$ was further subdivided by water depth, with the second splits' threshold being $197 \mathrm{~cm}$. For the dataset with values below $197 \mathrm{~cm}$, macrophyte coverage was estimated to be approximately $40 \%$. The data group with water depths $>197 \mathrm{~cm}$ was further split by Secchi depth $(113 \mathrm{~cm})$. When Secchi depth was larger than $113 \mathrm{~cm}$, macrophyte coverage (44\%) was two-fold higher compared to periods with less than $113 \mathrm{~cm}$ (21\%) (Figures 7a and 8a). As reflected in the CIT analysis, water level appears to be critical for the macrophyte coverage above 30\%, observed in 2001, 2005, 2007, and 2008 when the lake water levels were low. Especially in 2008 when the water level was at its lowest, the growth of submerged plants was at its highest, namely 60\% (Figure 8a) despite the lowest Secchi depth. No quantitative data on submerged plants are available from the period 1997-2000, but coverage was above 30\% ([20], M. Beklioğlu, pers. obs.).

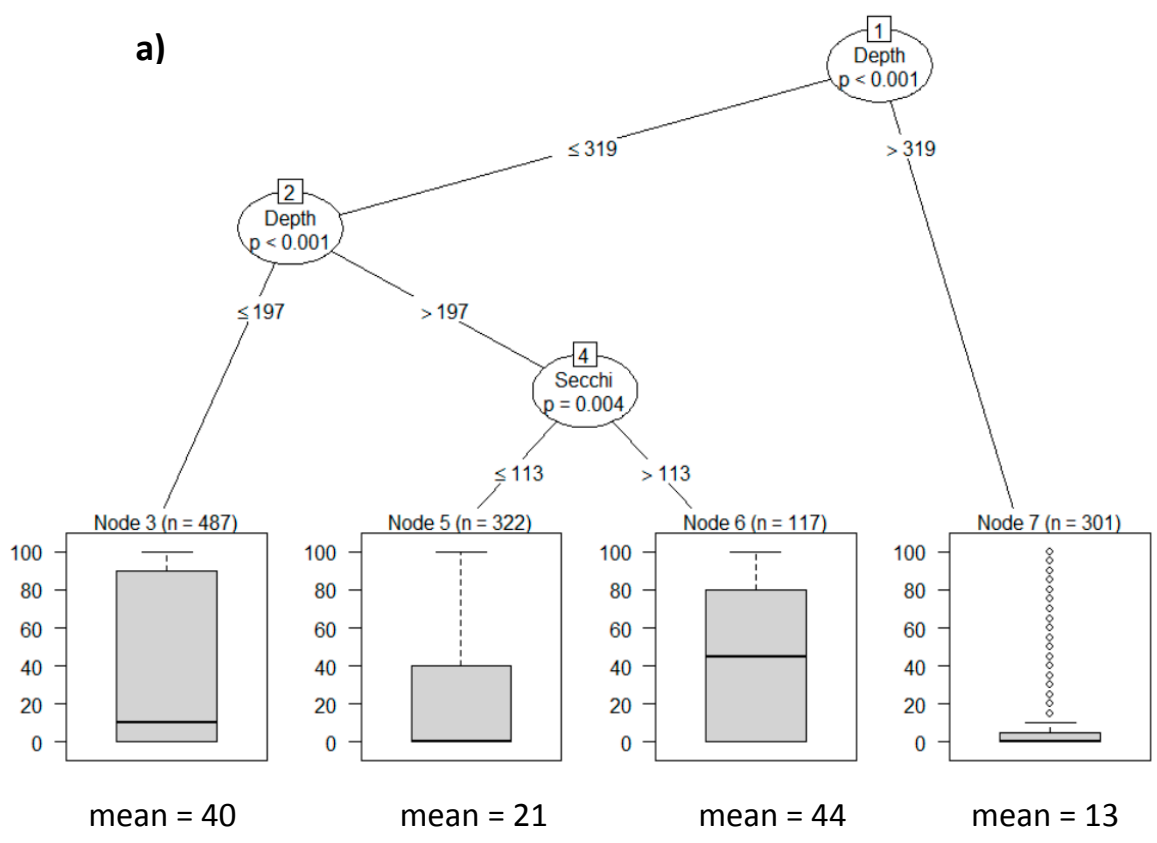

Figure 7. Cont. 


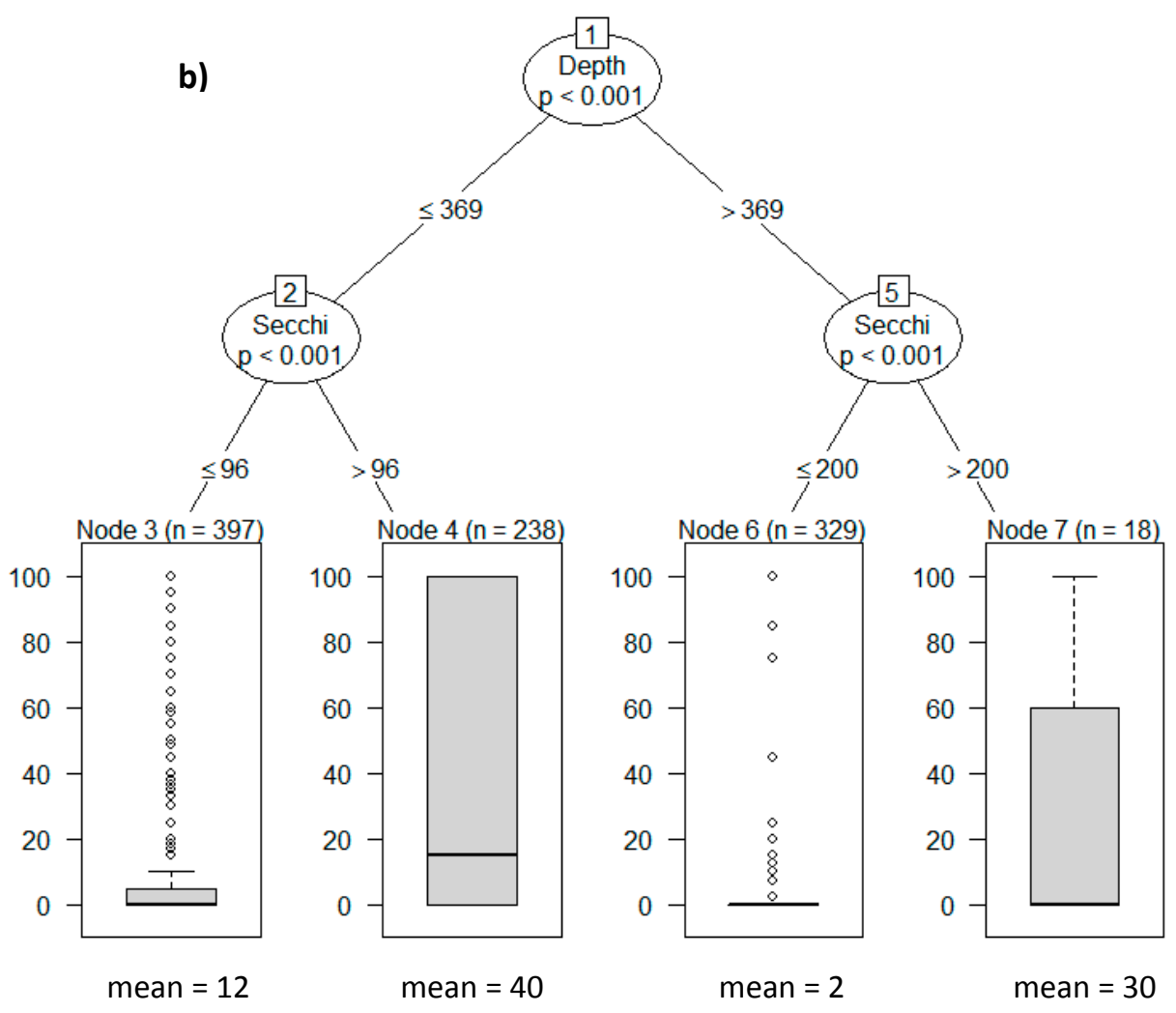

Figure 7. Conditional Inference Trees for (a) Lake Mogan and (b) Lake Eymir (Depth: water depth, Secchi: Secchi depth, n: number of sampling points, mean: mean macrophyte coverage). The data in the figure represent plant coverage and Secchi depth values measured at each transect point during the plant surveys each year.

In Lake Eymir the plant community largely consisted of S. pectinata and Ceratophyllum demersum. The CIT analysis revealed the first split in the tree for water depth and the second for Secchi depth. A new branch was formed in the dataset with water depths $>369 \mathrm{~cm}$ by Secchi depth. If the Secchi depth was $>200 \mathrm{~cm}$, the mean macrophyte coverage was 30\%, and almost no plants were found below $200 \mathrm{~cm}$. At water depth $\leq 369 \mathrm{~cm}$, macrophyte coverage was $40 \%$ when Secchi depth was higher than $96 \mathrm{~cm}$ : if below $96 \mathrm{~cm}$, coverage fell to $12 \%$ (Figures $7 \mathrm{~b}$ and $8 \mathrm{~b}$ ). Submerged plants responded to the significantly improved water clarity, increasing their coverage several-fold following the first fish removal (Figure 8b). This was in accordance with the CIT analysis result. The decrease in Secchi depth coincided with a reduction in plant coverage. Although the second biomanipulation undertaken between 2005 and 2013 led to enhanced water clarity, it remained low compared to the situation during the period after the first fish removal. Plant coverage also remained low, approximately $10 \%$ or less. Towards 2013 water level progressively increased, and the slight recovery in water clarity was probably not enough to allow for recovery of the submerged plant community (Figure 8b). This was in accordance with the results of the CIT analysis showing that macrophytes are unlikely to establish at high water depth. 


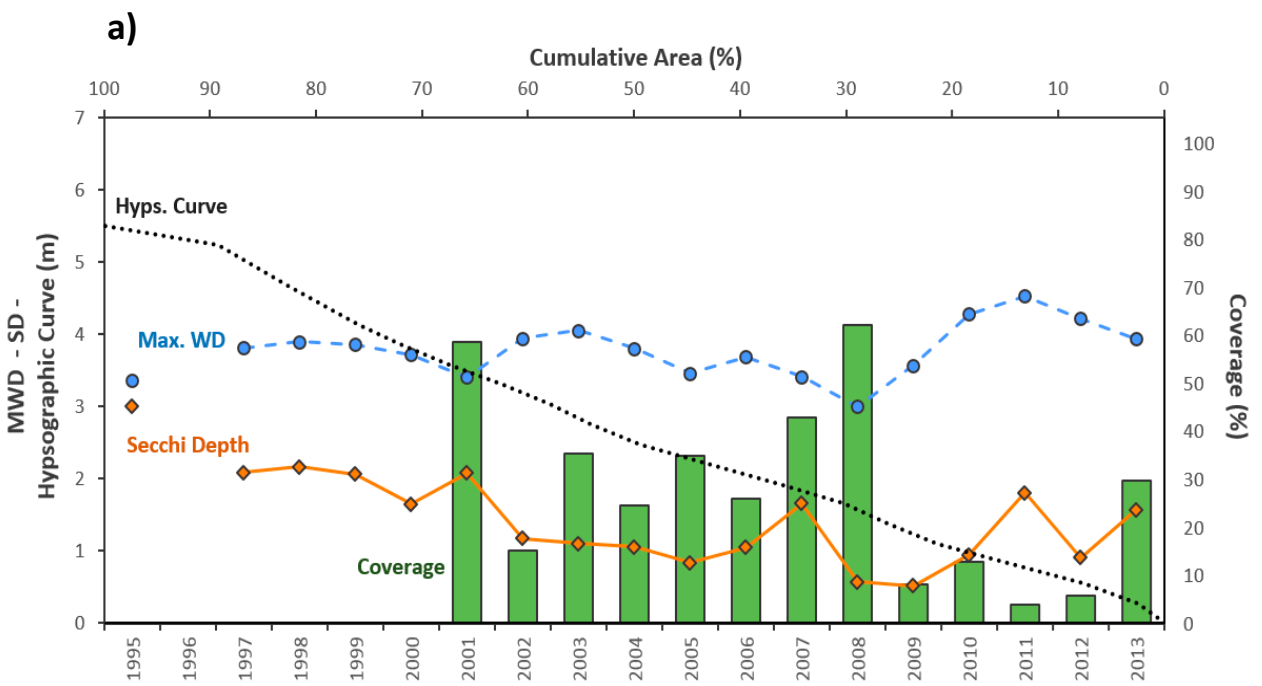

b)

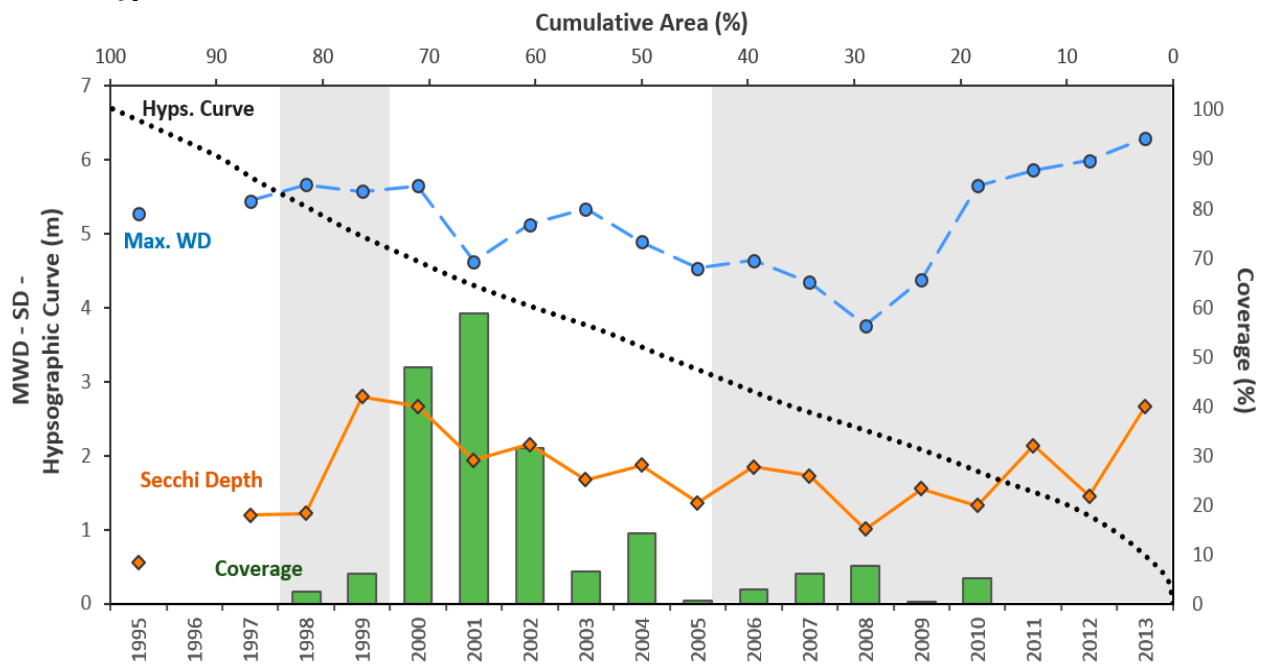

Figure 8. Changes in maximum water depth (MWD), Secchi depth (SD), hypsographic curve and \% submerged macrophyte coverage in (a) Lake Mogan and (b) Lake Eymir (shading indicates the first and second biomanipulation).

\subsection{Plankton}

During the study period in Lake Mogan, Chl- $a$ concentrations were generally low. GLM analysis revealed no significant relationship between Chl- $a$ and predictor variables of temperature, TP concentration, and zooplankton biomass. The phytoplankton community was largely dominated by cyanobacteria (Merismopedia sp., Anabaena sp.), whose contribution has increased markedly in recent years (Figure 9a,e). Phytoplankton yield, expressed as the Chl- $a$ to TP ratio (Chla:TP), also remained low (Figure 9c). The zooplankton community mostly consisted of calanoid copepod Arctodiaptomus bacillifer and rotifers Filinia longiseta, Brachionus spp., Keratella quadrata and Hexarthra sp., while cladocerans such as Daphnia magna, D. pulex, Ceriodaphnia sp. and Diaphanosoma lacustris represented only a minor proportion (Figure 9g). Grazing pressure expressed as the ratio of zooplankton to phytoplankton biomass (zoop:phyto) was generally high and varied between 0.1 to 4 (mean: $1.21 \pm 0.24$ ) (Figure 9i). 

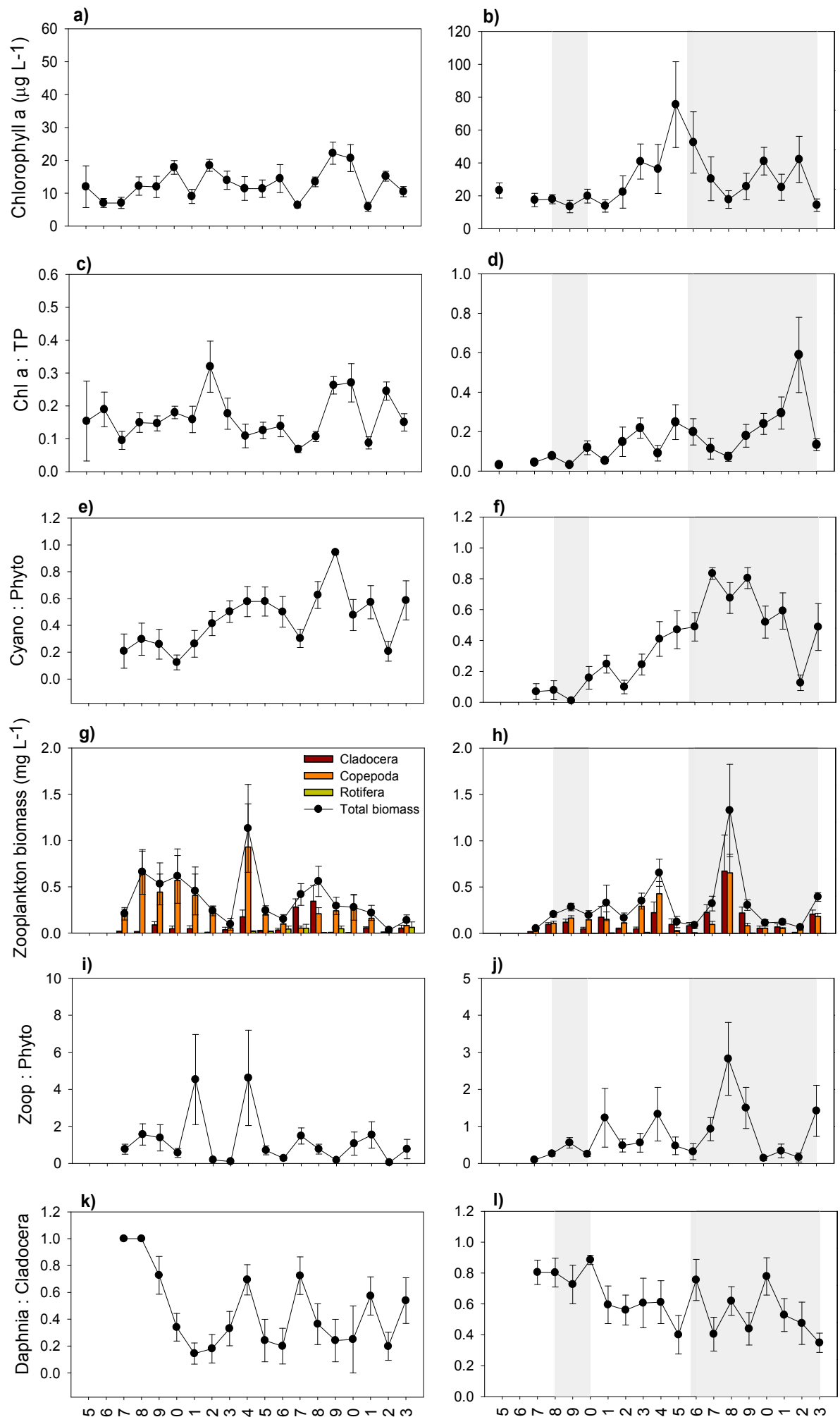

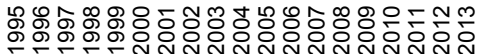

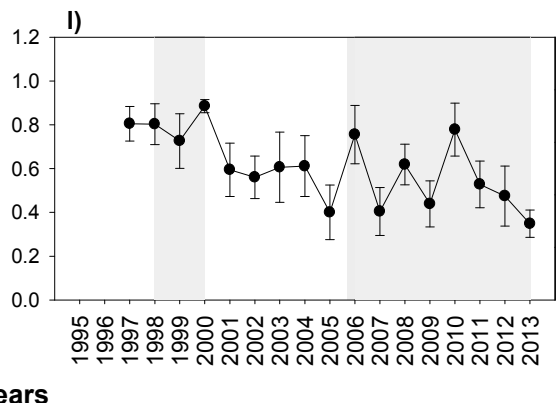

Figure 9. Changes in yearly mean (with $\pm \mathrm{SE}) ;(\mathbf{a}, \mathbf{b})$ Chlorophyll $a$; (c,d) Chla:TP (Phytoplankton yield); (e,f) cyanobacteria to total phytoplankton ratio; $(\mathbf{g}, \mathbf{h})$ zooplankton biomass; (i,j) zooplankton to phytoplankton ratio; (k,l) Daphnia to Cladocera ratio, in Lake Mogan (left panels) and in Lake Eymir (right panels) (shaded periods indicate the first and second biomanipulation). Note the scale differences on the $y$-axes. 
In Lake Eymir, Chl- $a$ concentration increased notably after the first biomanipulation until the second biomanipulation, but afterwards it varied substantially (Figure 9b). GLM analysis revealed that zooplankton top-down control was a major driver of the Chl- $a$ concentration decrease, since the zooplankton community was mainly dominated by large-sized calanoid copepods and cladocerans (see below), along with a marginally significant positive bottom-up effect of temperature $(p<0.01)$. Before and two years after the first biomanipulation, Chl- $a$ as well as the phytoplankton yield (Chla:TP) were low (Figure 9d), coinciding with a low DIN:SRP and an increased grazing ratio following the fish removal. However, Chl- $a$ concentration and the phytoplankton yield (Chla:TP) (excluding 2004) exhibited an increase (especially before the second biomanipulation), coinciding with a low grazing potential. The relative abundance of cyanobacteria (Anabaena sp., Anabenopsis sp., Chroococcus sp.) also increased from 2002 onwards (Figure 9f). The second fish removal, which started at the end of 2005 resulted in a major reduction of Chl- $a$ concentrations, though it largely varied from 2009 to 2013 (Figure 9b). Furthermore, the phytoplankton yield gradually increased, especially during the HWL period in 2009-2012 (Figure 9d). The grazing pressure increased from almost zero to approximately three and fluctuated significantly following the changes in zooplankton biomass induced through biomanipulation (Figure 9j). The zooplankton community dominated by large-sized calanoid copepods (A. bacillifer) and cladocerans (D. magna, D. pulex, D. brachyurum, Ceriodaphnia sp.), while rotifer contribution was low (Figure $9 \mathrm{~h}$ ). The total zooplankton biomass and the biomass of daphnids were very low before the fish removals and increased noticeably following the two periods of biomanipulations, but afterwards they varied largely. In 2008, when the water level was lowest, the zooplankton biomass was highest at the highest fish BPUE. The ratio of daphnid to cladoceran biomass remained higher during the two periods of biomanipulations, and it varied between 0.4 and 0.9 (Figure 91).

\section{Discussion}

Twenty years of monitoring data from two interconnected Anatolian lakes, Lake Mogan and Lake Eymir, suggest that sewage effluent diversion led to an immediate reduction of nutrient levels, yet without triggering a corresponding recovery in water clarity. Biomanipulation of Lake Eymir to boost improvement of the environmental state resulted in a major recovery of water clarity and recolonization of macrophytes. However, the recovery was short-lived and conditions deteriorated three years after the biomanipulation, probably due to already high nutrient concentrations and a decline in water level (especially occurring in 2004-2005). Nevertheless, with the onset of the second biomanipulation, $\mathrm{P}$ concentration largely dropped especially during the period of HWL occurring with high flushing, being at its lowest during the 20-year monitoring period. Therefore, the outcome of biomanipulation in Mediterranean lakes probably depends on the existing hydrological conditions during and after the biomanipulation, as proposed in our first hypothesis. We partly accept and partly reject the second hypothesis since the second biomanipulation led to some improvement of water clarity but without expansion of macrophytes. The lack of macrophyte expansion is probably related to the water level being too high to favor macrophyte growth despite improved water clarity. On the other hand, shallower Lake Mogan benefitted from the LWL conditions under which macrophytes flourished, and the LWL probably overcame the turbid conditions by enabling more light to reach an enlarged littoral habitat. Thus, our third hypothesis can be largely confirmed since during the LWL years, the lake maintained its macrophyte community.

It is widely accepted that external nutrient loading is the key factor determining the nutrient concentrations in lakes. In Lakes Mogan and Eymir, sewage effluent diversion in the early 1990s led to an approximately 50\% reduction of TP and DIN concentrations. Following effluent control, fish biomanipulation was undertaken, such manipulation being suggested as a successive step after diversion to promote recovery of eutrophic lakes. The success of biomanipulation is known to depend strongly on continued low nutrient concentrations [25,30,32,89-91]. Lake Eymir had higher nutrient concentrations than the suggested level to ensure recovery of a stratifying lake $(0.02 \mathrm{mg} \mathrm{P} / \mathrm{L})$ [26]. 
In Lake Eymir, P remained high also owing to the low P retention capacity especially compared to Lake Mogan (on average $27 \%$ and $94 \%$, respectively) most likely owing to the 25 years of raw sewage effluent discharge, and internal P loading especially in LWL years [19]. Coppens et al. [19] showed that during the LWL years with reduced precipitation and, increased evaporation, a 30\%-85\% reduction occurred in inflow discharge, resulting in a lake volume reduction of approximately $50 \%$ in both lakes. This led to a peak in nutrient concentrations via evaporative water loss as well as internal loading, especially in Lake Eymir, despite the absence of nutrient loading from the catchment [19]. Efficient flushing of lake water can help to dilute the nutrient concentrations, as suggested by Cooke et al. [25] and in accordance with this, HWL years in the recent period resulted in a high flushing rate and lower P concentrations. Our findings differ from results in Jeppesen et al. [33], showing that for most lakes a new equilibrium for TP can be expected after 15-20 years of sewage diversion and this was only marginally influenced by hydraulic retention time. Our results from Mediterranean lakes highlight that the recovery of lakes after a nutrient loading reduction as well as biomanipulation may be confounded by hydrological conditions. Furthermore, the ongoing global climate change is predicted to lead to even more frequent and intensive droughts [92] that may complicate the recovery efforts.

The recovery of the plank-benthivorous fish biomass soon after the fish removals likely contributed to the deterioration of the water quality through direct and indirect mechanisms. Such a fast recovery of fish biomass is not surprising as this was recorded earlier in other lakes at lower latitudes, including Mediterranean lakes where omnivorous small fish have fast reproduction cycles and longer spawning periods [47]. In warmer lakes, there is weaker top-down control of piscivorous fish as well as higher food availability in eutrophic conditions [34-37,47,93,94]. In Lake Eymir, although pike angling was banned after the first biomanipulation, no true recovery occurred, implying a lack of predator control of the plankti-benthivorous fish stock. In accordance with Jeppesen et al. [26] in Mediterranean lakes, maybe fish removal is not an as effective restoration method as in temperate lakes due to fast recovery of fish biomass that require repeated actions (see Jeppesen et al. [26] for a thorough discussion).

The macrophyte coverage in Lake Mogan appeared to be controlled significantly by the water level. When water level was low (ca. $<2 \mathrm{~m}$ according to CIT analysis), it became the major driver of macrophyte colonization, and plant coverage was higher regardless of water clarity. This was likely the case in 2008 when the macrophyte coverage peaked despite the fact that the Secchi depth was at its lowest level due to the high phytoplankton biomass. Moreover, the simultaneous increases in both WL and Secchi depth in 2009 and 2013 may explain the lack of changes in macrophyte coverage. Our results corroborate those of previous monitoring and experimental studies in Turkish lakes, showing that the water level overrides the effects of the turbid water conditions [39-41,52]. The CIT analysis revealed that not only water depth but also water clarity are critical factors for determining macrophyte growth in Lake Eymir. Improvement of the light climate following the first biomanipulation led to an immediate increase of the macrophyte coverage in Lake Eymir. Although the water clarity in summer was relatively low in 2001 compared to the previous years, the low water level compensated for the reduced clarity so that the coverage was the highest. However, this was not the case in 2007 and 2008 when the water levels were the lowest, the coverage remained very low. This probably resulted from the underestimation of the plant coverage as the fieldwork was carried out late in September when the plants probably had already died back (M. Beklioğlu, pers. obs.). However in the subsequent years, the benefits of the higher water clarity for macrophyte growth was offset by the high water level (see Figure $8 \mathrm{~b}$ ). Although the second biomanipulation in Lake Eymir enhanced the top-down control of phytoplankton, leading to enhanced water clarity, the macrophyte coverage, however, remained low. Probably improvement in water clarity was not sufficient as the water level was too high $(>6 \mathrm{~m})$ to allow macrophyte recolonization, as it was revealed in the CIT analysis that high water depth itself is a control factor that eliminates the occurrence of macrophytes.

In Lake Mogan, Chl- $a$ concentrations appeared to be lower when macrophytes were present (with the exception of 2011), which may be attributed to competition for nutrients as well as other stabilizing buffer mechanisms of macrophytes [42,95]. In addition to the bottom-up control of phytoplankton, 
the top-down control of zooplankters could also be important [96] as the zooplankton biomass was largely dominated by copepods, but daphnids were also present. In Lake Mogan, the phytoplankton biomass was also largely dominated by small colony-forming cyanobacteria (Merismopedia sp.) and $\mathrm{N}$-fixing species (Anabaena sp. and Anabaenopsis sp.). During years when the DIN:SRP ratio was low $(<13)$, cyanobacteria contribution to the phytoplankton biomass was important (Figures 6e and 9e) implying cyanobacteria dominance at N-limited conditions [97].

The low Chl- $a$ concentration, especially following the fish removals in Lake Eymir, was probably due to the large zooplankton grazing exerted by large cladocerans (see Figure 9j) indicating strong top-down control of phytoplankton biomass. During the second biomanipulation, the grazing pressure peaked in the lowest WL (2008), coinciding with a large decrease in Chl- $a$, though the fish biomass was also at its highest. This contradiction might have been due to the fish catch being more efficient in the low water levels as the lake lost half of its water volume and became shallower during 2008. The phytoplankton yield was low during the early period of the study implying a low TP to Chl- $a$ transfer efficiency [72,98] (Figure 9). This low transfer efficiency may also be a result of $\mathrm{N}$ limitation at higher TP levels [99]. In Lake Eymir, the very low DIN:SRP ratios (2-7) indicate strong N limitation (Figure 6f) due to the input of raw sewage effluents for 25 years. Cyanobacteria contributed substantially to the phytoplankton biomass of Lake Eymir (Anabaena sp., Anabaenopsis sp.) (Figure 9) and N-fixing cyanobacteria species may have benefitted from the lower $N$ concentrations during this period $[97,100]$. With the major drop in the TP concentration, the Chl-a:TP ratio increased, which may also be attributed to a balanced supply of $\mathrm{N}$ and $\mathrm{P}$.

Shallow lakes located in arid to semi-arid regions may also suffer from salinization due to evaporative water loss resulting from the prolonged hydraulic residence time [101,102]. In our study the lakes' salinity doubled in periods of LWLs when the HRT became longer than 100 years. This increase was probably not high enough to cause a major change, but it is worth noting that the doubling of the salinity occurred over a very short time period (2005-2009). Through global climate change, prolonged and more intensive drought periods may lead to even more severe salinization of freshwater lakes, which may reduce system resilience as saline lakes tend to be more eutrophic than freshwater lakes at similar nutrient levels [103].

To conclude, maintaining the ecological integrity and good ecological state of lakes, which are eutrophic to hypertrophic, located in semi-arid to arid climates during especially low water level periods is a huge challenge as nutrients may become up-concentrated through evaporative volume loss, a factor that is likely to reduce ecosystem resilience, as seen in Lake Eymir. In Lake Eymir, fish removal created immediate positive effects [20,56], but a long-lasting recovery appears to be difficult to achieve due to the high nutrient availability. In warm lakes, constraints of hydrology (e.g., low water level and high HRT) further preclude the success of biomanipulation. When fish removal was undertaken during wet periods with high flushing or dilution rates, the reductions of nutrient levels and phytoplankton biomass appeared to be likely, which may positively contribute to recovery. However, the recolonization of macrophytes depends on the lake morphometry as well as the water level. As in shallower Lake Mogan, macrophyte abundance increased in periods with low water levels even at turbid water. In the future, the global climate change and its expected warmer, prolonged, and intensified droughts will pose a challenge to lake managers. When introducing management/restoration measures, the rhythm of the hydrological cycle of freshwater ecosystems must be taken into account for success.

Acknowledgments: This study received logistic support from the Middle East Technical University (METU), which also provided major funding by the BAP programme, and from TÜBİTAK ÇAYDAG 110 Y125 during 2010-2013. The MARS project (Managing Aquatic Ecosystems and Water Resources under Multiple Stress) funded under the 7th EU Framework Programme, Theme 6 (Environment including Climate Change), Contract No.: 603378 (http: / / www.mars-project.eu), funded the authors during the writing up phase. The contributions of Tuba Bucak, Nur Filiz and Jan Coppens were supported by the TÜBITAK 2211 and 2215 programmes, while the contributions of Şeyda Erdoğan and Arda Özen were supported by the METU-DPT ÖYP programme of Turkey (BAP-08-11-DP T-2002-K120510) and those of Gizem Bezirci, Ü. Nihan Tavşanoğlu, A. İdil Çakıroğlu and 
Eti E. Levi by TÜBITAK ÇAYDAG (Project no: 105Y332, 109Y181 and 110Y125). We would also like to thank Levent Burnak and Can Ozan Tan, who collected data during the initial phase of the monitoring. Finally, we are grateful to Erik Jeppesen for inviting us to contribute to this issue and Anne Mette Poulsen, Sara Banu Akkaş, and Jennifer Kalvenas for editorial assistance.

Dedication: We would like to dedicate this manuscript to the memory of Aykut Kence, who passed away in February 2014, a great, insightful scientist and the founder of various research fields, including freshwater ecology, at the Biological Sciences Department of Middle East Technical University, Turkey.

Author Contributions: Meryem Beklioğlu wrote the paper and designed the study; Ü. Nihan Tavşanoğlu identified the zooplankton species; Şeyda Erdoğan and Arda Özen identified the cyanobacteria species; Tuba Bucak, Jan Coppens and Eti E. Levi conducted the statistical analyses; Tuba Bucak, Jan Coppens, Gizem Bezirci, Ü. Nihan Tavşanoğlu, Eti E. Levi, Şeyda Erdoğan, A. İdil Çakıroğlu, Nur Filiz, Korhan Özkan and Arda Özen performed sampling and laboratory analyses and contributed to the writing of the paper.

Conflicts of Interest: The authors declare no conflicts of interest. The funding sponsors had no role in the design of the study; in the collection, analysis, or interpretation of the data; in the writing of the manuscript; or in the decision to publish the results.

\section{References}

1. Costanza, R.; Graumlich, L.; Steffen, W.; Crumley, C.; Dearing, J.; Hibbard, K.; Leemans, R.; Redman, C.; Schimel, D. Sustainability or collapse: What can we learn from integrating the history of humans and the rest of nature? Ambio 2007, 36, 522-527. [CrossRef]

2. Howden, S.M.; Soussana, J.F.; Tubiello, F.N.; Chetri, N.; Dunlop, M.; Meinke, H. Adapting agriculture to climate change. Proc. Natl. Acad. Sci. USA 2007, 104, 19691-19696. [CrossRef] [PubMed]

3. Jeppesen, E.; Kronvang, B.; Meerhoff, M.; Søndergaard, M.; Hansen, K.M.; Andersen, H.E.; Lauridsen, T.L.; Liboriussen, L.; Beklioğlu, M.; Özen, A.; et al. Climate change effects on runoff, catchment phosphorus loading and lake ecological state, and potential adaptations. J. Environ. Qual. 2009, 38, 1930-1941. [CrossRef] [PubMed]

4. Jeppesen, E.; Kronvang, B.; Olesen, J.E.; Audet, J.; Søndergaard, M.; Hoffmann, C.C.; Andersen, H.E.; Lauridsen, T.L.; Liboriussen, L.; Larsen, S.E.; et al. Climate change effects on nitrogen loading from cultivated catchments in Europe: Implications for nitrogen retention, ecological state of lakes and adaptation. Hydrobiologia 2011, 663, 1-21. [CrossRef]

5. Özen, A.; Karapınar, B.; Kucuk, I.; Jeppesen, E.; Beklioglu, M. Drought-induced changes in nutrient concentrations and retention in two shallow Mediterranean lakes subjected to different degrees of management. Hydrobiologia 2010, 646, 61-72. [CrossRef]

6. Romo, S.; Soria, J.; Fernández, F.; Ouahid, Y.; Baró-Solá, A. Water residence time and the dynamics of toxic cyanobacteria. Freshw. Biol. 2012, 58, 513-522. [CrossRef]

7. Beklioğlu, M.; Meerfhoff, M.; Søndergaard, M.; Jeppesen, E. Eutrophication and Restoration of Shallow Lakes from a Cold Temperate to a Warm Mediterranean and a (sub) Tropical Climate. In Eutrophication: Causes, Consequences and Control; Ansari, A.A., Gill, S.S., Lanza, G.R., Rast, W., Eds.; Springer: Dordrecht, The Netherlands, 2011; pp. 91-108.

8. Jeppesen, E.; Brucet, S.; Naselli-Flores, L.; Papastergiadou, E.; Stefanidis, K.; Nõges, T.; Nõges, P.; Attayde, J.L.; Zohary, T.; Coppens, J.; et al. Ecological impacts of global warming and water abstraction on lakes and reservoirs due to changes in water level and related changes in salinity. Hydrobiologia 2015, 750, 201-227. [CrossRef]

9. Cai, J.B.; Ding, X.F.; Peng, H.Y.; Chang, H.Q.; Yang, X.E. Effects of environmental factors and submerged aquatic plants on phosphorus release from the sediment. J. Soil Water Conserv. 2007, 21, 151-154.

10. Yang, X.; Wu, X.; Hao, H.; He, Z. Mechanisms and assessment of water eutrophication. J. Zhejiang Univ. Sci. B 2008, 9, 197-209. [CrossRef] [PubMed]

11. Yvon-Durocher, G.; Montoya, J.M.; Trimmer, M.; Woodward, G. Warming alters the size spectrum and shifts the distribution of biomass in freshwater ecosystems. Glob. Chang. Biol. 2010, 17, 1681-1694. [CrossRef]

12. Dossena, M.; Yvon-Durocher, G.; Grey, J.; Montoya, J.M.; Perkins, D.M.; Trimmer, M.; Woodward, G. Warming alters community size structure and ecosystem functioning. Proc. R. Soc. B 2012, 37-49. [CrossRef] [PubMed]

13. Wrona, F.J.; Prowse, T.D.; Reist, J.D.; Hobbie, J.E.; Levesque, L.M.J.; Vincent, W.F. Climate change effects on aquatic biota, ecosystem structure and function. Ambio 2006, 35, 359-369. [CrossRef] 
14. Trenberth, K.E.; Dai, A.; van der Schrier, G.; Jones, P.D.; Barichivich, J.; Briffa, K.R.; Sheffield, J. Global warming and changes in drought. Nat. Clim. Chang. 2014, 4, 17-22. [CrossRef]

15. Wantzen, K.M.; Rothhaupt, K.-O.; Mörtl, M.; Cantonati, M.; Tóth, L.G.; Fischer, P. Ecological effects of water-level fluctuations in lakes: An urgent issue. Hydrobiologia 2008, 613, 1-4. [CrossRef]

16. Christensen, J.H.; Kanikicharla, K.K.; Marshall, G.; Turner, J. Climate phenomena and their relevance for future regional climate change. In Climate Change 2013: The Physical Science Basis. Contribution of Working Group I to the Fifth Assessment Report of the Intergovernmental Panel on Climate Change; Stocker, T.F., Qin, D., Plattner, G.-K., Tignor, M.M.B., Allen, S.K., Boschung, J., Nauels, A., Xia, Y., Bex, V., Midgley, P.M., Eds.; Cambridge University Press: Cambridge, UK; New York, NY, USA, 2013; pp. 1217-1308.

17. Erol, A.; Randhir, T.O. Climatic change impacts on the ecohydrology of Mediterranean watersheds. Clim. Chang. 2012, 114, 319-341. [CrossRef]

18. Leblanc, M.J.; Tregoning, P.; Ramillien, G.; Tweed, S.O.; Fakes, A. Basin-scale, integrated observations of the early 21st century multiyear drought in southeast Australia. Water Resour. Res. 2009, 45. [CrossRef]

19. Coppens, J.; Özen, A.; Tavşanoğlu, Ü.N.; Erdoğan, Ş.; Levi, E.E.; Yozgatlıgil, C.; Jeppesen, E.; Beklioğlu, M. Impact of alternating wet and dry periods on long-term seasonal phosphorus and nitrogen budgets of two shallow Mediterranean lakes. Sci. Total Environ. 2016, 563-564, 456-467. [CrossRef] [PubMed]

20. Beklioğlu, M.; Tan, C.O. Restoration of a Shallow Mediterranean Lake by biomanipulation complicated by drought. Fundam. Appl. Limnol. 2008, 171, 105-118. [CrossRef]

21. Søndergaard, M.; Jensen, J.P.; Jeppesen, E. Role of sediment and internal loading of phosphorus in shallow lakes. Hydrobiologia 2003, 506/509, 135-145. [CrossRef]

22. Breukelaar, A.W.; Lammens, E.H.R.R.; Breteler, J.G.P.K.; Tatrai, I. Effects of benthivorous bream (Abramis brama) and carp (Cyprinus carpio) on sediment resuspension and concentrations of nutrients and chlorophyll-a. Freshw. Biol. 1994, 32, 113-121. [CrossRef]

23. Vanni, M.J.; Layne, C.D.; Arnott, S.E. “Top-down” trophic interactions in lakes: Effects of fish on nutrient dynamics. Ecology 1997, 78, 1-20.

24. Vanni, M.J. Nutrient cycling by animals in freshwater ecosystems. Annu. Rev. Ecol. Syst. 2002, 33, 341-370. [CrossRef]

25. Cooke, G.D.; Welch, E.B.; Peterson, S.A.; Nichols, S.A. Restoration and Management of Lakes and Reservoirs, 3rd ed.; Taylor \& Francis: London, UK; New York, NY, USA, 2005.

26. Jeppesen, E.; Meerhoff, M.; Davidson, T.A.; Trolle, D.; Søndergaard, M.; Lauridsen, T.L.; Beklioğlu, M.; Brucet, S.; Volta, P.; Gonzalez-Bergonzoni, I.; et al. Climate change impacts on lakes: An integrated ecological perspective based on a multi-faceted approach, with special focus on shallow lakes. J. Limnol. 2014, 73, 88-111. [CrossRef]

27. Moss, B.; Madgewick, J.; Phillips, G. A Guide to the Restoration of Nutrient-Enriched Shallow Lakes; Broads Authority and Environment Agency: Norwich, UK, 1996; p. 180.

28. Søndergaard, M.; Jeppesen, E.; Lauridsen, T.L.; Skov, C.; Van Nes, E.H.; Roijackers, R.; Lammens, E.; Portielje, R.O.B. Lake restoration: Successes, failures and long-term effects. J. Appl. Ecol. 2007, 44, 1095-1105. [CrossRef]

29. Meijer, M.L.; Jeppesen, E.; van Donk, E.; Moss, B.; Scheffer, M.; Lammens, E.; van Nes, E.; van Berkum, J.A.; de Jong, G.J.; Faafeng, B.A.; et al. Longterm responses to fish-stock reduction in small shallow lakes: Interpretation of five-year results of four biomanipulation cases in The Netherlands and Denmark. Hydrobiologia 1994, 275, 457-466. [CrossRef]

30. Jeppesen, E.; Sammalkorpi, I. Lakes. In Handbook of Ecological Restoration; Perrow, M.R., Davy, A.J., Eds.; Cambridge University Press: Cambridge, UK, 2002; Volume 2, pp. 297-324.

31. Sas, H. Lake Restoration by Reduction of Nutrient Loading: Expectations, Experiences and Extrapolations; Academia Verlag Richarz: St Augustin, Germany, 1989; p. 497.

32. Søndergaard, M.; Liboriussen, L.; Pedersen, A.R.; Jeppesen, E. Lake restoration by fish removal: Short-and long-term effects in 36 Danish lakes. Ecosystems 2008, 11, 1291-1305. [CrossRef]

33. Jeppesen, E.; Søndergaard, M.; Mazzeo, N.; Meerhoff, M.; Branco, C.; Huszar, V.; Scasso, F. Lake Restoration and Biomanipulation in Temperate Lakes. In Tropical Eutrophic Lakes: Their Restoration and Management, 3rd ed.; Reddy, M.V., Ed.; Taylor \& Francis Group: Boca Raton, FL, USA, 2005; pp. 331-359.

34. Lazzaro, X. Do the trophic cascade hypothesis and classical biomanipulation approaches apply to tropical lakes and reservoirs? Verh. Int. Verein. Limnol. 1997, 26, 719-730. 
35. González-Bergonzoni, I.; Meerhoff, M.; Davidson, T.A.; Teixeira-de Mello, F.; Baattrup-Pedersen, A.; Jeppesen, E. Meta-analysis shows a consistent and strong latitudinal pattern in fish omnivory across ecosystems. Ecosystems 2012, 15, 492-503. [CrossRef]

36. Blanck, A.; Lamouroux, N. Large-scale intraspecific variation in life-history traits of 44 European freshwater fish. J. Biogeogr. 2007, 34, 862-875. [CrossRef]

37. Lappalainen, J.; Tarkan, A.S. Latitudinal gradients in onset date, onset temperature and duration of spawning of roach. J. Fish Biol. 2007, 70, 441-450. [CrossRef]

38. Welch, E.B. The Dilution/Flushing technique in Lake Restoration. J. Am. Water Resour. Assoc. 1981, 17, 558-564. [CrossRef]

39. Beklioğlu, M.; Altınayar, G.; Tan, C.O. Water level control over submerged macrophyte development in five shallow lakes of Mediterranean Turkey. Fundam. Appl. Limnol. 2006, 166, 535-556. [CrossRef]

40. Özkan, K.; Jeppesen, E.; Johansson, L.S.; Beklioğlu, M. The response of periphyton and submerged macrophytes to nitrogen and phosphorus loading in shallow warm lakes: A mesocosm experiment. Freshw. Biol. 2010, 55, 463-475. [CrossRef]

41. Bucak, T.; Saraoğlu, E.; Levi, E.E.; Tavşanoğlu, Ü.N.; Çakıroğlu, A.İ.; Jeppesen, E.; Beklioğlu, M. The influence of water level on macrophyte growth and trophic interactions in eutrophic Mediterranean shallow lakes: A mesocosm experiment with and without fish. Freshw. Biol. 2012, 57, 1631-1642. [CrossRef]

42. Engelhardt, K.A.M.; Ritchie, M.E. Effects of macrophyte species richness on wetland ecosystem functioning and services. Nature 2001, 411, 687-689. [CrossRef] [PubMed]

43. Jeppesen, E.; Søndergaard, M.; Søndergaard, M.; Christoffersen, K. The Structuring Role of Submerged Macrophytes in Lakes; Springer: New York, NY, USA, 1998.

44. Bachmann, R.W.; Horsburgh, C.A.; Hoyer, M.V.; Mataraza, L.K.; Canfield, D.E., Jr. Relations between trophic state indicators and plant biomass in Florida lakes. Hydrobiologia 2002, 470, 219-234. [CrossRef]

45. Meerhoff, M.; Iglesias, C.; de Mello, F.T.; Clemente, J.M.; Jensen, E.; Lauridsen, T.L.; Jeppesen, E. Effects of habitat complexity on community structure and predator avoidance behaviour of littoral zooplankton in temperate versus subtropical shallow lakes. Freshw. Biol. 2007, 52, 1009-1021. [CrossRef]

46. Tavşanoğlu, Ü.N.; Çakıroğlu, A.İ.; Erdoğan, Ş.; Meerhoff, M.; Jeppesen, E.; Beklioğlu, M. Sediments, not plants, offer the preferred refuge for Daphnia against fish predation in Mediterranean shallow lakes: An experimental demonstration. Freshw. Biol. 2012, 57, 795-802. [CrossRef]

47. Jeppesen, E.; Moss, B.; Bennion, H.; Carvalho, L.; de Meester, L.; Feuchtmayr, H.; Friberg, N.; Gessner, M.O.; Hefting, M.; Lauridsen, T.L.; et al. Interaction of climate change and eutrophication. In Climate Change Impacts on Freshwater Ecosystems; Blackwell Publishing: Oxford, UK, 2010; pp. 119-151.

48. Jeppesen, E.; Meerhoff, M.; Holmgren, K.; González-Bergonzoni, I.; Teixeira-de Mello, F.; Declerck, S.A.; de Meester, L.; Søndergaard, M.; Lauridsen, T.L.; Bjerring, R.; et al. Impacts of climate warming on lake fish community structure and potential effects on ecosystem function. Hydrobiologia 2010, 646, 73-90. [CrossRef]

49. Destouni, G.; Jaramillo, F.; Prieto, C. Hydroclimatic shifts driven by human water use for food and energy production. Nat. Clim. Chang. 2013, 3, 213-217. [CrossRef]

50. Peel, M.C.; Finlayson, B.L.; McMahon, T.A. Updated world map of the Köppen-Geiger climate classification. Hydrol. Earth Syst. Sci. 2007, 11, 1633-1644. [CrossRef]

51. Turkish State Meteorological Service. Available online: http://www.meteoroloji.gov.tr/index.aspx (accessed on 10 March 2014).

52. Coops, H.; Beklioğlu, M.; Crisman, T.L. The role of water-level fluctuations in shallow lake ecosystems-Workshop conclusions. Hydrobiologia 2003, 506, 23-27. [CrossRef]

53. Özesmi, U. Ecology and Politics of Rehabilitation: Mogan Lake Wetland System, Ankara, Turkey. In An International Perspective on Wetland Rehabilitation; Streever, W., Ed.; Kluwer Academic Publishers: Dordrecht, The Netherlands, 1999; pp. 181-187.

54. BirdLife International, Important Bird and Biodiversity Area Factsheet: Mogan Lake. Available online: http:/ / www.birdlife.org (accessed on 14 May 2016).

55. Burnak, S.L.; Beklioğlu, M. Macrophyte-dominated clearwater state of Lake Mogan. Turk. J. Zool. 2000, 24, 305-314.

56. Beklioğlu, M.; Ince, O.; Tüzün, I. Restoration of the eutrophic lake Eymir, Turkey, by biomanipulation after a major external nutrient control. Hydrobiologia 2003, 490, 93-105. [CrossRef] 
57. Altınbilek, D.; Usul, N.; Yazıcıŏlu, H.; Kutoğlu, Y.; Merzi, N.; Göğüs, M.; Doyuran, V.; Günyaktı, A. Gölbaşı Mogan-Eymir Gölleri için su Kaynakları ve Çevre Yönetim Planı Projesi; Technical Report No: 93-03-03-04-01; Middle East Technical University: Ankara, Turkey, 1995. (In Turkish)

58. Balık, S.; Geldiay, R. Türkiye Tatlısu Balıkları; Ege Üniversitesi Su Ürünleri Fakültesi Yayınları: Bornova, Turkey, 2002; p. 46.

59. Kuru, M. Türkiye İçsu Balıklarının Son Sistematik Durumu. GÜ Gazi Eğitim Fak. Derg. 2004, 24, 1-21.

60. Alas, A.; Solak, K. The reproductive biology of the tench (Tinca tinca L., 1758) in Kayaboğazı (Kütahya, Turkey) Dam Lake. Turk. J. Vet. Anim. Sci. 2005, 28, 879-885.

61. Levi, E.E.; Çakıroğlu, A.İ.; Bucak, T.; Odgaard, B.V.; Davidson, T.A.; Jeppesen, E.; Beklioğlu, M. Similarity between contemporary vegetation and plant remains in the surface sediment in Mediterranean lakes. Freshw. Biol. 2014, 59, 724-736. [CrossRef]

62. Davis, P.H. Flora of Turkey and the East Aegean Islands; Edinburgh University Press: Edinburgh, UK, 1984; Volume 8.

63. Seçmen, Ö.; Leblebici, E. Türkiye'nin Sulak alan Bitkileri ve Bitki Örtüsü; Ege Üniversitesi Fen Fakültesi Yayınları: İzmir, Turkey, 1997; p. 870.

64. Mackereth, F.J.H.; Heron, J.; Talling, J.F. Water Analysis: Some Revised Methods for Limnologists; Freshwater Biological Association: Ambleside, UK, 1978; p. 120.

65. Jespersen, A.M.; Christoffersen, K. Measurements of chlorophyll- $a$ from phytoplankton using ethanol as extraction solvent. Fundam. Appl. Limnol. 1987, 109, 445-454.

66. Reynolds, C.S. The Ecology of Freshwater Phytoplankton; Cambridge University Press: Cambridge, UK, 1984; p. 387.

67. Hillebrand, H.; Dürselen, C.D.; Kirschtel, D.; Pollingher, U.; Zohary, T. Biovolume calculation forpelagic and bentic microalgae. J. Phycol. 1999, 35, 403-424. [CrossRef]

68. Wetzel, R.G.; Likens, G.E. Limnological Analyses, 2nd ed.; Springer: New York, NY, USA, 1991; p. 429.

69. John, D.M.; Whitton, B.A.; Brook, A.J. The Freshwater Algal Flora of the British Isles; Cambridge University Press: Cambridge, UK, 2002.

70. Prescott, G.W. Algea of the Western Great Lakes Area (with on Illustrated Ket to the Genera of Desmids and Freshwater Diatoms); Wm. C. Brown Company Publishers: Dubuque, IA, USA, 1973.

71. Scourfield, D.J.; Harding, J.P. A Key to the British Freshwater Cladocera with Notes on Their Ecology, 3rd ed.; Freshwater Biological Association: Ambleside, UK, 1966.

72. Ruttner-Kolisko, A. Plankton Rotifers: Biology and Taxonomy; English Translation of Die Binnengewisser; Lubrecht \& Cramer: Stuttgart, Germany, 1974; Volume XXVI.

73. Pontin, R.M. A Key to the British Freshwater Planktonic Rotifera; Freshwater Biological Association No. 38; Scientific Publication: Cumbria, UK, 1978; p. 178.

74. Einsle, U. Süßwasserfauna von Mitteleuropa; Gustav Fisher Verlag: Stuttgart/Jena, Germany; New York, NY, USA, 1993; Volume 1, p. 208.

75. Segers, H. Rotifera. Vol. 2: The Lecanidae (Monogononta). In Guides to the Identification of the Microinvertebrates of the Continental Waters of the World 6; Dumont, H.J., Nograty, T., Eds.; SPB Academic Publishing: The Hague, The Netherlands, 1995; p. 226.

76. Smirnov, N.N. Cladocera: The Chydorinae and Sayciinae (Chydoridae) of the world. In Guides to the Identification of the Microinvertebrates of the Continental Waters of the World 11; Dumont, H.J., Ed.; SPB Academic Publishing: The Hague, The Netherlands, 1996; p. 197.

77. Flößner, D. Die Haplopoda und Cladocera (ohne Bosminidae) Mitteleuropas; Backhuys Publishers: Leiden, The Netherlands, 2000; p. 428.

78. Smith, D.G. Pennak's Freshwater Invertebrates of the United States: Porifera to Crustacea, 4th ed.; John Wiley and Sons: New York, NY, USA, 2001.

79. Dumont, H.; de Velde, I.V.; Dumont, S. The dry weight estimate of biomass in a selection of Cladocera, Copepoda and Rotifera from the plankton, periphyton and benthos of continental waters. Oecologia 1975, 19, 75-97. [CrossRef]

80. Bottrell, H.H.; Duncan, A.; Gliwicz, Z.M.; Grygierek, E.; Herzig, A.; Hillbricht-Ilkowska, A.; Kurusawa, H.; Larsson, P.; Weglenska, T. A review of some problems in zooplankton production studies. Norw. J. Zool. 1976, 24, 419-456. 
81. McCauley, E. The Estimation of the Abundance and Biomass of Zooplankton in Samples. In A Manual on Methods for the Assessment of Secondary Productivity in Freshwaters, 2nd ed.; Downing, J.A., Rigler, F.H., Eds.; Blackwell Scientific Publication: New York, NY, USA, 1984; pp. 228-265.

82. Malley, D.F.; Lawrence, S.G.; Maclever, M.A.; Finlay, W.J. Range and variation in estimates of dry weight for planktonic Crustacea and Rotifera from temperate North American Lakes. Can. Tech. Rep. Fish. Aquat. Sci. 1989, 1666, 1-49.

83. Michaloudi, E. Dry weights of zooplankton of Lake Mikri Prespa (Macedonia, Greece). Belg. J. Zool. 2005, 135, 223-227.

84. R Core Team. R: A Language and Environment for Statistical Computing; R Foundation for Statistical Computing: Vienna, Austria, 2016.

85. Environmental Systems Research Institute. ArcGIS Desktop: Release 10; Environmental Systems Research Institute: Redlands, CA, USA, 2012.

86. Prasad, A.M.; Iverson, L.R.; Liaw, A. Newer Classification and Regression Tree Techniques: Bagging and Random Forests for Ecological Prediction. Ecosystems 2006, 9, 181-199. [CrossRef]

87. Hothorn, T.; Hornik, K.; Zeileis, A. Unbiased Recursive Partitioning: A Conditional Inference Framework. J. Comp. Graph. Stat. 2006, 15, 651-674. [CrossRef]

88. Hothorn, T.; Everitt, B.S. A Handbook of Statistical Analyses Using R; CRC Press: Boca Raton, FL, USA; Taylor and Francis Group: Oxfordshire, UK, 2014.

89. Benndorf, J. Possibilities and limits for controlling eutrophication by biomanipulation. Int. Rev. Gesamten Hydrobiol. 1995, 80, 519-534. [CrossRef]

90. Hansson, L.A.; Annadotter, H.; Bergman, E.; Hamrin, S.F.; Jeppesen, E.; Kairesalo, T.; Luokkanen, E.; Nilsson, P.Å.; Søndergaard, M.; Strand, J. Biomanipulation as an application of food-chain theory: Constraints, synthesis, and recommendations for temperate lakes. Ecosystems 1998, 1, 558-574. [CrossRef]

91. Jeppesen, E.; Søndergaard, M.; Lauridsen, T.L.; Davidson, T.A.; Liu, Z.; Mazzeo, N.; Trochine, C.; Özkan, K.; Jensen, H.S.; Trolle, D.; et al. Biomanipulation as a restoration tool to combat eutrophication: Recent advances and future challenges. Adv. Ecol. Res. 2012, 47, 411-487.

92. Nowlin, W.H.; Evarts, J.L.; Vanni, M.J. Release rates and potential fates of nitrogen and phosphorus from sediments in a eutrophic reservoir. Freshw. Biol. 2005, 50, 301-322. [CrossRef]

93. Jeppesen, E.; Søndergaard, M.; Kanstrup, E.; Petersen, B.; Eriksen, R.B.; Hammershøj, M.; Mortensen, E.; Jensen, J.P.; Have, A. Does the Impact of Nutrients on the Biological Structure and Function of Brackish and Freshwater Lakes Differ? In Nutrient Dynamics and Biological Structure in Shallow Freshwater and Brackish Lakes; Springer: Dordrecht, The Netherlands, 1994; pp. 15-30.

94. Gyllström, M.; Hansson, L.A.; Jeppesen, E.; Garcia-Criado, F.; Gross, E.; Irvine, K.; Kairesalo, T.; Kornijow, R.; Miracle, M.R.; Nykanen, M.; et al. The role of climate in shaping zooplankton communities of shallow lakes. Limnol. Oceanogr. 2005, 50, 2008-2021. [CrossRef]

95. Van Donk, E.; van de Bund, W.I. Impact of submerged macrophytes including charophytes on phyto- and zooplankton communities: Allelopathy versus other mechanisms. Ecol. Charophytes 2002, 72, 261-274. [CrossRef]

96. Jeppesen, E.; Søndergaard, M.; Jensen, J.P. Climate warming and regime shifts in lake food webs-Some comments. Limnol. Oceanogr. 2003, 48, 1346-1349. [CrossRef]

97. Morris, D.P.; Lewis, W.M., Jr. Phytoplankton nutrient limitation in Colorado mountain lakes. Freshw. Biol. 1988, 20, 315-327. [CrossRef]

98. Chow-Fraser, P.; Trew, D.O.; Findlay, D.; Stainton, M. A test of the hypothesis to explain the sigmoid relationships between total phosphorus and chlorophyll concentrations in Canadian lakes. Can. J. Fish. Aquat. Sci. 1994, 51, 2052-2065. [CrossRef]

99. May, L.; Spears, B.M.; Dudley, B.J.; Hatton-Ellis, T.W. The importance of nitrogen limitation in the restoration of Llangorse Lake, Wales, UK. J. Environ. Monit. 2010, 12, 338-346. [CrossRef] [PubMed]

100. Fogg, G.E. The Leeuwenhoek Lecture, 1968: The physiology of an algal nuisance. Proc. R. Soc. Lond. B Biol. Sci. 1969, 173, 175-189. [CrossRef] 
101. Intergovernmental Panel on Climate Change. Summary for Policymakers. In Climate Change 2014: Impacts, Adaptation, and Vulnerability. Part A: Global and Sectoral Aspects. Contribution of Working Group II to the Fifth Assessment Report of the Intergovernmental Panel on Climate Change; Field, C.B., Barros, V.R., Dokken, D.J., Mach, K.J., Mastrandrea, M.D., Bilir, T.E., Chatterjee, M., Ebi, K.L., Estrada, Y.O., Genova, R.C., Eds.; Cambridge University Press: Cambridge, UK; New York, NY, USA, 2014; pp. 1-32.

102. Wetzel, R.G. Limnology, 2nd ed.; Saunders College Publishing: New York, NY, USA, 1983; p. 767.

103. Talling, J.F. Environmental controls on the functioning of shallow tropical lakes. Hydrobiologia 2001, 458, 1-8. [CrossRef]

(C) 2017 by the authors; licensee MDPI, Basel, Switzerland. This article is an open access article distributed under the terms and conditions of the Creative Commons Attribution (CC BY) license (http:/ / creativecommons.org/licenses/by/4.0/). 